\title{
Club Convergence in EU Countries: A Sectoral Perspective
}

\author{
Eleonora Cavallaro $^{1+}$ and Ilaria Villani ${ }^{1}$ \\ ${ }^{1}$ Sapienza University of Rome, Italy
}

\begin{abstract}
We employ Phillips and Sul's (2007) nonlinear dynamic factor model to investigate whether economic integration within the EU has caused countries' productive structures to become increasingly similar and sector-level productivity to converge over the period 1995-2018. This analysis provides several results. First, the EU countries do not converge to a unique path; instead, we observe clustered patterns for aggregate and sector-level productivity growth. Second, although successful integration in global production networks enabled most Central-Eastern European countries to catch up to other EU countries, asymmetries have increased following the recent financial crisis. Third, the heterogeneity in countries' long-run productivity levels reflects differences in their vertical specialization; countries approaching the high-growth paths specialize in knowledge-intensive production, and the foreign value-added content of their exports is lower. Our analysis is relevant to the ongoing debate on the effects of internationalizing production, as it sheds light on countries' growth prospects and indicates possible directions for policy actions.
\end{abstract}

Keywords: Club convergence, Dynamic factor model, Economic integration, Vertical specialization, Global value chain

JEL Classifications: C33, C38, O47, F6

Received 10 November 2019, Revised 10 August 2020, Accepted 30 November 2020

\section{Introduction}

Whether economic integration has led to real income convergence in Europe remains an open question. Given the severe consequences of the financial turmoil that began with the 2007 global financial crisis and was amplified by the outbreak of the sovereign bond crisis, the EU faces increasing uncertainty regarding the prospects of social and economic cohesion among its members. These goals are expected to accompany economic convergence owing to the EU's common market and its Structural Funds and Cohesion Policy for regional disparities. Although real income disparities across the EU fell considerably over the last decades, this trend has stopped and unresolved asymmetries remain, jeopardizing the convergence process

\footnotetext{
+Corresponding Author: Eleonora Cavallaro

Professor, University of Rome, Sapienza, Department of Economics and Law, Via del Castro Laurenziano, 9, I-00161

Rome, Italy, Email: eleonora.cavallaro@uniroma1.it

Co-Author: Ilaria Villani

Ph.D. student, University of Rome, Sapienza, Department of Economics and Law, Via del Castro Laurenziano, 9, I-00161 Rome, Italy, Email: ilaria.villani@uniroma1.it
} 
(Bolea et al., 2018; Borsi \& Metiu, 2015; Monfort et al., 2013). From a theoretical perspective, the competitive forces activated by the common market are expected to deliver nominal and real convergence, but agglomerative factors can also be important drivers of growth. Such factors act as self-enforcing mechanisms that exacerbate the original asymmetries and economic divide across the EU, in line with the core-periphery model (Baldwin \& Wyplosz, 2009; Krugman, 1991). Moreover, the nonlinear effects of financial deepening on growth and the macroeconomic imbalances associated with rapid growth in the financial sectors raise the question of what type of financial integration is conducive to risk sharing and income smoothing (Beck et al., 2016; Hoffman \& Sorensen, 2015; Kremer \& Popov, 2018). Thus, macroeconomic policies and tools should be reconsidered at the national and EU levels to address the multiple paces of growth within Europe and establish a more resilient growth convergence process.

Although a financial shock from abroad initially triggered the crisis in Europe, country-specific characteristics eventually created distinct vulnerabilities and heterogeneous responses to the crisis. A critical factor in this heterogeneity was the dissimilarity in economies' productive structures. These productive structures incorporate two distinct dimensions of countries' specialization: the horizontal dimension, associated with the sectoral composition of output, and the vertical dimension, related to products' technological content within a given industry and the distinction between upstream and downstream production. Both dimensions are relevant to countries' growth prospects. Although productive structures became increasingly similar across most European countries, with services playing a greater role relative to traditional sectors, cross-country differences in the real incomes generated at the sector level are still relevant and reflect both the demand and supply determinants of countries' vertical specializations. Several authors use factor endowments to argue that skill-abundant countries exploit their comparative advantages in the production of high-quality goods. Specifically, advanced economies compete in qualitydominated markets (Aiginger, 1997), whereas low-skilled economies engage in price competition and produce downstream products. To the extent that high-quality products incorporate advanced skills and command high market prices, they generate high incomes for advanced economies. In line with Linder's (1961) hypothesis, wealthier countries consume high-quality goods in larger proportions than poorer countries do (Bils \& Klenow, 2001; Brooks, 2006; Crinò \& Epifani, 2012; Hallak, 2010), and, as a result, bilateral flows in high-quality goods characterize trade between rich countries. At the same time, economic integration promotes the international diffusion of knowledge and enables technological upgrades, increasing catching-up countries' competitiveness in high-income markets (Cavallaro et al., 2013). Successful participation in global production networks therefore serves to boost productivity growth at the sector level and enables economic convergence.

The literature provides evidence that the two-way trade in skill-intensive products between the Central and Eastern European countries (CEECs) and the core European countries is playing 
an increasing role as a consequence of foreign direct investment (FDI) inflows and the trade in intermediate goods (Dulleck et al., 2005). This role is also strongly enhanced by the region's ongoing economic integration (Landesmann et al., 2009; Landesmann \& Stehrer, 2007; Schott, 2004). Traditional gravity variables and linguistic and geographical proximity significantly explain trade flows related to global value chain participation, and empirical studies of the CEECs confirm that bilateral sector-level FDI stock is positively associated with both gross bilateral trade and the bilateral import content of the sector's exports (Aiyar et al., 2013; Buelens \& Tirpák, 2017). Nevertheless, the way in which countries participate in global production networks impacts their long-run growth. Related studies focus on the roles of economies' productive structures when production occurs at a global level. Some countries assemble final goods from imported parts and components, and, thus, their exports are very import-intensive and are characterized by lower domestic value-added content. Other countries specialize in the design and engineering phases of output and produce the high-value components that are used by the countries that assemble final goods. This distinction has important implications for the increasing competition from less developed economies, whose labor cost advantages offset other costs of offshoring, leading to continuous change in the global production network's structure. Thus, international competition challenges firms in less advanced EU countries to upgrade their vertical specialization within the global value chain $(\mathrm{GVC})$ so that they can retain high-value segments of production (Baldwin \& Lopez-Gonzalez, 2014; Baldwin \& Venables, 2013; Hummels et al., 2001). From a policy perspective, attracting FDI is an indirect way of deepening GVC participation and should be largely encouraged. At the same time, supporting firm-level upgrades in the context of specific challenges should be a primary goal for countries aiming to reap the benefits of international production networks.

Recent literature on European integration focuses on the issue of real convergence or divergence. Palan and Schmiedeberg (2010) apply time-series and panel-data techniques to employment data from fourteen Western European countries and find strong intersectoral convergence at the total economy level, with the services sectors taking an increasing share. However, they observe widening divergence in technology-intensive manufacturing industries characterized by economies of scale, path dependency, and strong economic growth. Sondermann (2014) employs unit root tests to assess productivity convergence in the euro area over the period 1970-2007. He rejects the assumption of convergence at the aggregate level and finds mixed evidence of reduced dispersion for specific subsectors of the economies depending on the specific methodology used. Bolea et al. (2018) use an input-output analysis for the period 2000-2014 to detect changes after the global financial crisis. The results suggest a strong reduction in the convergence of productive structures across the EU. Their analysis builds upon the GVC literature that distinguishes between intra- and extra-EU trade and domestic components, and it confirms that the medium-low technology manufacturing sector, along with routine 
services, is driving the CEECs' process of catching up to other EU economics. In contrast, knowledge-intensive sectors remain prevalent in the core EU countries. Califano and Gasperin (2019) investigate the performance disparities within a select group of countries. They divide these countries into four distinct groups, namely, the core, semi-core, southern periphery, and German-sphere eastern countries, according to their degrees of involvement with German industrial production networks. They show that, over the period 1995-2015, the southern countries fell behind, the eastern countries caught up, and the core and semi-core countries forged ahead. In their analysis, the convergence pattern is largely explained by the displacement of the southern EU countries' exports of both final consumption and intermediate goods to Germany due to the eastern EU countries' increasing role in the German production networks.

Against this background, this study analyzes the sector-level convergence in real incomes across EU countries. We employ the nonlinear factor model proposed by Phillips and Sul (2007, 2009) (henceforth, PS). This model is based on the notion of $\sigma$-convergence (Barro \& Sala-i-Martin, 1992; Mankiw et al., 1992), which describes countries' tendency to reduce income dispersion. Unlike other approaches, the PS methodology allows for transitional divergent dynamics. The technique follows two steps: a convergence test for the panel and an iterative procedure to identify endogenously converging clubs and, thus, avoid a priori groupings.

From a theoretical perspective, the neoclassical Solow growth model prescribes absolute income convergence across countries with identical technologies, but Baumol (1986), Romer (1986), and Lucas (1988) argue that absolute convergence is rarely observed. Along these lines, Azariadis and Drazen (1990), Azariadis (1996), and Galor (1996) explain that countries may not converge to a unique long-run steady state but rather form convergence clubs in the presence of heterogeneity in initial factor endowments or structural conditions. Heterogeneity in structural factors may refer to differences in technologies and income distributions and the existence of market imperfections. Club convergence is a type of conditional convergence that emphasizes the initial conditions; countries will approach a unique long-run growth path only if their initial conditions are in the same so-called "basin of attraction." From a normative perspective, this concept enables structural policy actions, as countries can undertake the appropriate reforms to close the gaps in initial conditions that are responsible for divergent growth paths.

Empirically, the possibility of real-world technological heterogeneity undermines the consistency of the Solow model parameter estimates (Pesaran \& Smith, 1995; Robertson \& Symons, 1992). This drawback has led to much empirical work aimed at developing appropriate methodologies for convergence tests. Within the literature, two classes of models can be distinguished: cross-sectional regressions of the augmented Solow model, following the initial work of Barro and Sala-i Martin (1992), Mankiw et al. (1992), and Islam (1995), and the time-series models for unit root and cointegration tests, following Evans and Karras (1996) and Evans (1998). The literature also explores the possibility of nonparametric or semiparametric methods (Baltagi 
\& Li, 2002; Cai \& Li, 2008; Li \& Stengos, 1996).

Among the cross-sectional models, Parente and Prescott (1994), Barro and Sala-i-Martin (1997), Basu and Weil (1998), Perez-Sebastian (2000), and Howitt and Mayer-Foulkes (2005) introduce a country-specific technology function. To address the need for new methodologies (Bernard \& Durlauf, 1996), Phillips and Sul (2007) introduce a nonlinear factor model that accounts for transitional dynamics. This methodology is drawing increasing attention and popularity among researchers aiming to empirically assess income convergence. In particular, Bartkowska and Riedl (2012), Lyncker and Thoennessen (2017), and Cutrini (2019) use it at the EU regional level, and Apergis et al. (2010), Monfort et al. (2013), and Borsi and Metiu (2015) use it for EU country-level analyses. These studies find no overall economic convergence at either the national or regional level but rather observe the formation of several convergence clubs.

This study contributes to the literature on European integration by using the PS nonlinear factor model to determine productivity convergence along the sectoral dimension. To the best of our knowledge, this study is the first attempt to employ the PS methodology to understand structural convergence across EU countries. Our analysis highlights that countries' participation in upstream or downstream production determines sector-level cross-country differences in value added that ultimately affect the overall economies' long-run productivity growth.

We are particularly interested in assessing the resilience of the ongoing integration process to adverse shocks by evaluating whether the distance in sectoral productivity across countries has increased. Thus, we first analyze the evolution of convergence from 1995 to 2018 and then focus on the more recent sub-period of 2007 to 2018 to consider the developments that occurred after the global financial crisis and the euro area sovereign bond crisis. Relative to the baseline period, we find that EU countries do not converge to a unique steady-state growth path in the more recent sub-period at either the aggregate or the sector level. In line with the results of related studies at the aggregate level, we find that the clusters are geographically distributed, with the northwestern EU countries forging ahead, the CEECs failing to close the gap in the long run because the more dynamic sectors fail to sufficiently catch up, and the peripheral countries clearly falling behind.

Overall, the aggregate-level heterogeneity across EU countries is the result of both the sectoral composition of output and differences in long-run sectoral productivity dynamics. We therefore conclude that the EU integration process is fragile in the sense that structural differences are not erased and convergence has halted. Our analysis is relevant to the debate on the structural reforms that countries should enact to reduce their income gaps.

The remainder of this paper is organized as follows. Section 2 explains the data and describes the empirical methodology. In Sections 3 and 4, we identify the productivity convergence clubs for the aggregate economies and their distinct sectors, respectively. Section 5 analyzes the relationship between the identified long-run patterns and countries' positions in global production 
networks, and Section 6 concludes.

\section{Data and Methodology}

We use annual data from Eurostat on purchasing power parity (PPP)-adjusted gross value added (GVA) for the period 1995-2018 for 27 EU countries.1) Adjusting for PPP enables more reliable comparisons between countries that are at different stages of their development processes and, thus, have not fully converged in price dynamics. Following the approach taken by more recent studies, we use hours worked rather than employment as an input measure to avoid biased results for productivity owing to heterogeneous developments in labor markets across the EU. The sector-level convergence analyses are restricted to the main sectors, corresponding to the $\mathrm{A}^{*} 10$ industry breakdown, as PPP-adjusted data are not available for more detailed sectors. We then use the OECD Trade in Value Added (TIVA) dataset to collect data on industries' value-added content in countries' exports and exports' foreign value-added intensity. We use these data, which are available at a more disaggregated level, to uncover countries' specializations in different skill-intensive industries and knowledge-intensive services and their participation in GVCs, which have implications for the sectoral convergence results.

The PS methodology is an empirical approach for studying economic transition and convergence. It builds upon the technology-augmented neoclassical growth model by allowing for heterogeneity across space and over time. This approach differs from other methods in that transitional divergence is treated as a possible outcome that does not ultimately preclude growth convergence. Empirically, this possibility is realized by introducing cross-sectional and time-series heterogeneity in the neoclassical model's technology parameters. As a result, the transition dynamics of real per capita income take the following functional form:

$$
\log y_{i t}=\log \tilde{y}_{i}^{*}+\log A_{i 0}+\left[\log \tilde{y}_{i 0}-\log \tilde{y}_{i}^{*}\right] e^{-\beta_{i t}}+x_{i t} t
$$

where $y_{i t}$ is the real per capita income of country $i$ at time $t ; \tilde{y}_{i 0}^{*}$ and $\tilde{y}_{i}^{*}$ are the initial and steady-state levels of per capita real income, respectively; $A_{i 0}$ is the initial value of the technology; $x_{i t}$ is the time-varying coefficient of the exponential function that describes the evolution of

1) We do not include Malta in the analysis owing to a lack of data, whereas we do include the UK, as it was an EU member state during the time period that we analyse. Countries acceded to the EU on different dates. After the Treaty of Rome, the group of six co-founders, that is, Belgium, France, Germany, Italy, Luxembourg, and the Netherlands acceded in 1958, followed by Denmark, Ireland, and the UK in 1973; Greece in 1981; Portugal and Spain in 1986; and Austria, Finland, and Sweden in 1995. A second wave comprising the so-called new accession countries followed, with Cyprus, the Czech Republic, Estonia, Hungary, Latvia, Lithuania, Poland, Slovakia, and Slovenia joining the EU in 2004; Bulgaria and Romania joining in 2007; and Croatia joining in 2013. 
the state of technology (i.e., $A_{i t}=A_{i 0} e^{x_{i t}}$ ); and $\beta_{i t}$ is the adjustment speed of country $i$ at time $t$. This model builds upon the neoclassical growth model in that the speed of convergence $\beta_{i t}$ and the rate of technical progress $x_{i t}$ are specific to country $i$ and vary over time. Because $e^{-\beta_{i t}} \rightarrow 0$ as $t \rightarrow \infty$, the long-run path of $\log y_{i t}$ is ultimately determined by the term $x_{i t} t$; thus, cross-country differences in real income are driven by differences in the rate of technological accumulation. PS represent equation (1) as a nonlinear factor model:

$$
\log y_{i t}=a_{i t}+x_{i t}
$$

where $a_{i t}$ embodies the transitional dynamics and $x_{i t}$ represents the idiosyncratic paths of technological progress over time. The $x_{i t}$ component contains elements that are common across countries, such as a common technology, which is represented by $\mu_{t}$. Equation (2) can be rewritten as:

$$
\log y_{i t}=\left(\frac{a_{i t}+x_{i t} t}{\mu_{t}}\right) \mu_{t}=\delta_{i t} \mu_{t} .
$$

In equation (3), $\mu_{t}$ represents the common steady-state growth path, that is, the latent unobservable common factor, and $\delta_{i t}$ is a time-varying idiosyncratic factor loading and measures the heterogeneous transition path of country $i$ to $\mu_{t}$. Hence, $\delta_{i t}$ measures the extent to which country $i$ benefits from the common technological frontier. Over the transition process, $\delta_{i t}$ varies. If the country converges to $\mu_{t}$, the individual transition coefficient $\delta_{i t}$ converges toward $\delta$ as $t \rightarrow \infty$.

The common factor is unobservable, and, hence, PS choose a formulation such that it is removed from the estimation. They do so by considering the relative transition coefficient $h_{i t}$, that is,

$$
h_{i t}=\frac{\log y_{i t}}{N^{-1} \sum_{i=1}^{N} \log y_{i t}}=\frac{\delta_{i t}}{N^{-1} \sum_{i=1}^{N} \delta_{i t}}
$$

which gives the logarithm of country $i$ 's output as a share of the average of the logarithm of each country's output at time $t$. Convergence is attained when the relative transition coefficient, $h_{i t}$, approaches unity as $t \rightarrow \infty$, or, equivalently, when:

$$
H_{t}=N^{-1} \sum_{i=1}^{N}\left(h_{i t}-1\right)^{2} \rightarrow 0, \text { as } t \rightarrow \infty .
$$


The crucial parameter to be estimated for convergence is $\delta_{i t}$. Including both the temporal and spatial dimensions means that the number of parameters to be estimated is excessive. To address this issue, PS propose the following semiparametric specification of $\delta_{i t}$ :

$$
\delta_{i t}=\delta_{i}+\sigma_{i} \xi_{i t} L(t)^{-1} t^{-\alpha}
$$

where $\delta_{i}$ is the time-invariant part of the country-specific factor loading $\delta_{i t}, L(t)$ is a slowly varying increasing function $(L(t) \rightarrow \infty$ as $t \rightarrow \infty), \alpha$ is the decay rate of the cross-sectional variation over the transitions (i.e., the speed of convergence), and $\xi_{i t}$ is a weakly autocorrelated random error variable (i.e., $\xi_{i t}$ is iid $\left.(0,1)\right)$.

The PS methodology has two steps. First, panel convergence is assessed using the so-called $\log -t$ test, and, second, a clustering algorithm is implemented to carry out the log- $t$ test for subsets of data when the null hypothesis of convergence is rejected for the full sample.

The null and alternative hypotheses are:

$$
\begin{aligned}
& H_{0}: \delta_{i}=\delta \text { with } \alpha \geq 0 \text { for all } i \\
& H_{1}: \delta_{i} \neq \delta \text { for all } i, \text { or } \delta_{i}=\delta \text { with } \alpha<0 .
\end{aligned}
$$

These hypotheses imply overall divergence if $\delta_{i} \neq \delta$ for all $i$ with $\alpha<0$ or club convergence if $\delta_{i} \neq \delta$ for some $i$ with $\alpha \geq 0.2$ )

Under the null hypothesis of growth convergence, the log-t regression model is formulated as:

$$
\log \left(H_{1} / H_{t}\right)-2 \log L(t)=a+b \log t+u_{t}
$$

for $t=[r T],[r T]+1, \ldots, T$ and $L(t)=\log t$ for $T$ up to 50. Here, $r \in[0.2,0.3]$ denotes the fraction of the initial sample that is removed before running the regression. This data trimming enables a focus on the transitional dynamics of the later period, in line with the test's intended asymptotic properties.

The statistical analysis (T-Stat) is the one-sided $t$-test for $\alpha \geq 0$ using $\hat{b}=2 \hat{\alpha}$ and heteroscedasticity- and autocorrelation-consistent (HAC) standard errors. The null hypothesis of convergence is rejected at the $5 \%$ level if $\hat{t}_{b}<-1.65$. The interpretation of the coefficient $\hat{b}$ is crucial; specifically, we observe convergence over time if $\hat{b}>0$ and divergence if $\hat{b}<0$

2) As Phillips and Sul (2009) explain, the null hypothesis implies relative convergence between country $i$ and country $j$, which can be defined as $\lim _{\mathrm{T} \rightarrow \infty}\left(\log y_{i t} / \log y_{j t}\right)=1$ and is also known as growth convergence. In contrast, level convergence (Bernard \& Durlauf, 1996; Evans \& Karras, 1996) is defined as $\lim _{\mathrm{T} \rightarrow \infty}\left(\log y_{i t}-\log y_{j t}\right)=0$. For $0 \leq \alpha<1$ convergence occurs in growth rates. 
When $\hat{b}$ is not significantly different from zero but the $t$-statistic is above the threshold value, we cannot rule out the possibility of convergence (Phillips \& Sul, 2009, p. 1168). The term $2 \log L(t)$ acts as a penalty function to avoid upward biased estimates of $\hat{b}$ under the alternative hypothesis. Finally, we use a HAC estimator for the covariance of $\hat{b}$ to compute the $t$-statistic because the regression errors are serially correlated.

PS illustrate the iterative procedure for detecting clubs in detail. Briefly, the units (countries) are first sorted in descending order based on the last period in the time series. Second, a convergence club is formed by adding units $(k)$ one by one to a group of the regions with the two highest incomes at the beginning of the period. A core group $G_{k}$ is established if $\hat{t}_{b}(k=2)>-1.65$. Then, for each additional unit, a log- $t$ test is run, and the number of units in the group is increased up to $n$, for which the condition $\hat{t}_{b}(k=n)>-1.65$ is rejected. At that point, the $n$-th unit is dropped, and the three-step procedure is repeated to identify additional clubs. If no more clubs are found, then it follows that the remaining units diverge. Finally, an additional club-merging step may be necessary to avoid "finding more clubs than the true number" (Phillips \& Sul, 2009, p. 1171). This step entails running the log-t regression for all pairs of initial clubs and merging the clubs that jointly fulfil the convergence hypothesis.

\section{Long-Run Growth in the EU: Productivity Convergence Clubs at the Aggregate Level}

We first apply the PS methodology to test for convergence in the full panel after eliminating the business cycle from the model using the Hodrick-Prescott (H-P) filter. ${ }^{3)}$ Then, we identify the clubs according to descending levels of the logarithm of GVA per hour worked. We employ the adjusted method proposed by Schnurbus et al. (2017), who use a slightly modified procedure to form clubs.4) Table 1 reports the results of the convergence test for the full panel. We use the log-treg routine developed for Stata users ( $\mathrm{Du}, 2017)$. We reject the null hypothesis for the full sample because the $T$-stat $\left(\hat{t}_{b}\right)$ is largely below the threshold level of -1.65 . Table

3) The data filtering procedure may impact the estimates depending on the business cycle filter used. In general, the filter choice depends on the application. We use the H-P filter, as suggested by PS, because our dataset is relatively small. Compared to other filters, such as the Christiano-Fitzgerald (CF), the H-P filter identifies turning-point signals in a timely and stable manner. The CF method has a high percentage of sign changes and is recommended for long time series (Nilsson \& Gyomai, 2011). For robustness, we perform further tests on our panel using an alternative high-pass filter (i.e., the Butterworth (1930) filter). Our results remain unchanged, and we identify the same clubs.

4) In the adjusted algorithm, the sieve criterion for forming clubs is slightly different: countries are added sequentially from the complementary group on the basis of the highest $t_{\hat{b}}$ obtained in the individual logttest, if the critical value -1.65 is fulfilled jointly. This avoids manual interventions to raise the parameter $c$ (in step two) in case the threshold condition fails to be fulfilled jointly. 
1 also shows which clubs are identified when we use 0.3 as the value for trimming the first part of the sample, as suggested by PS.

Table 1. Results of Log $t$ test for Productivity, Total Economy, 1995-2018

\begin{tabular}{|c|c|c|c|c|c|c|}
\hline & $\begin{array}{c}\text { No. of } \\
\text { Countries }\end{array}$ & $b$ & $T$-Stat & SE & $\begin{array}{l}\text { GVA phw } \\
1995 \\
\text { (Average) }\end{array}$ & $\begin{array}{l}\text { GVA phw } \\
2018 \\
\text { (Average) }\end{array}$ \\
\hline WHOLE SAMPLE & 27 & -0.5538 & -17.7532 & 0.0312 & 26.20 & 33.38 \\
\hline $\begin{array}{l}\text { Club } 1 \\
\text { Belgium, Denmark, France, } \\
\text { Germany, Ireland, Luxembourg }\end{array}$ & 6 & -0.0917 & -1.5724 & 0.0583 & 38.00 & 51.80 \\
\hline $\begin{array}{l}\text { Club } 2 \\
\text { Austria, Finland, Italy, Lithuania, } \\
\text { Netherlands, Poland, Romania, Slovenia, } \\
\text { Spain, Sweden, United Kingdom }\end{array}$ & 11 & 0.0013 & 0.0202 & 0.0638 & 26.37 & 33.61 \\
\hline $\begin{array}{l}\text { Club } 3 \\
\text { Croatia, Cyprus, Czechia, Estonia, Greece, } \\
\text { Hungary, Latvia, Portugal, Slovakia }\end{array}$ & 9 & 0.3488 & 6.7513 & 0.0517 & 19.17 & 22.86 \\
\hline $\begin{array}{c}\text { DIVERGENT } \\
\text { Bulgaria }\end{array}$ & 1 & - & - & - & - & - \\
\hline
\end{tabular}

We observe that global convergence is not achieved; instead, several subgroups of countries each converge to a different productivity growth rate. We identify three clubs, with Bulgaria diverging. The estimation results point to weak membership for Clubs 1 and 2 because the estimated coefficient $b$ is very close to zero (and even negative for Club 1). Nevertheless, we cannot reject the assumption of convergence at the $5 \%$ significance level because the $T$-Stat is above the threshold. The magnitude of the coefficient $b$ for Clubs 2 and 3 implies conditional convergence, that is, convergence in growth rates, because $0 \leq b<20$. All of the estimated $b$ values are very small, implying that the countries converge at an extremely slow pace, as the decay rate of the cross-sectional variations in the transitions, $\hat{\alpha}=\frac{b}{2}$, is very small (see equation (6)).

The most noticeable feature emerging from the data is that the clusters are geographically identified, supporting related literature on real income convergence at the national level (Borsi \& Metiu, 2015; Monfort et al., 2013). Club 1 includes northwestern EU countries that joined the EU earlier, namely, Belgium, Denmark, France, Germany, Ireland, and Luxembourg. Club 2 is a more heterogeneous and less geographically concentrated cluster that includes both old and new EU member states. It includes Finland, Sweden, Netherlands, and the UK in the northern EU; Austria in the central EU; Italy and Spain in the southern EU; and a group of new member states in the central and eastern EU, that is, Lithuania, Poland, Romania, and Slovenia. The clustering reflects countries' estimated long-run convergence given their initial 
conditions or structural adjustments. For the new EU member states in Club 2, the pace at which they are closing their initial productivity gap explains their club membership. Club 3 includes all the remaining new members of the EU, namely, Croatia, Cyprus, the Czech Republic, Estonia, Hungary, Latvia, and Slovakia, and some older members in the southern EU, that is, Greece and Portugal. Overall, the results based on evaluating countries' dynamic behavior over more than two decades suggest that only a few new EU member states are likely to successfully catch up.

Figure 1 illustrates the distance between clubs, measured by the club-average transition paths, $\bar{h}_{C_{s} t}$. The paths remain flat, and the distance among the clubs is unresolved. This result is in line with recent studies that identify a lack of convergence in productivity and real incomes across the EU. We also show the relatively unfavorable position of Bulgaria, which diverges (dotted line).

Figure 1. Club average transition paths, $\bar{h}_{C t}$, total economy productivity, 1995-2018

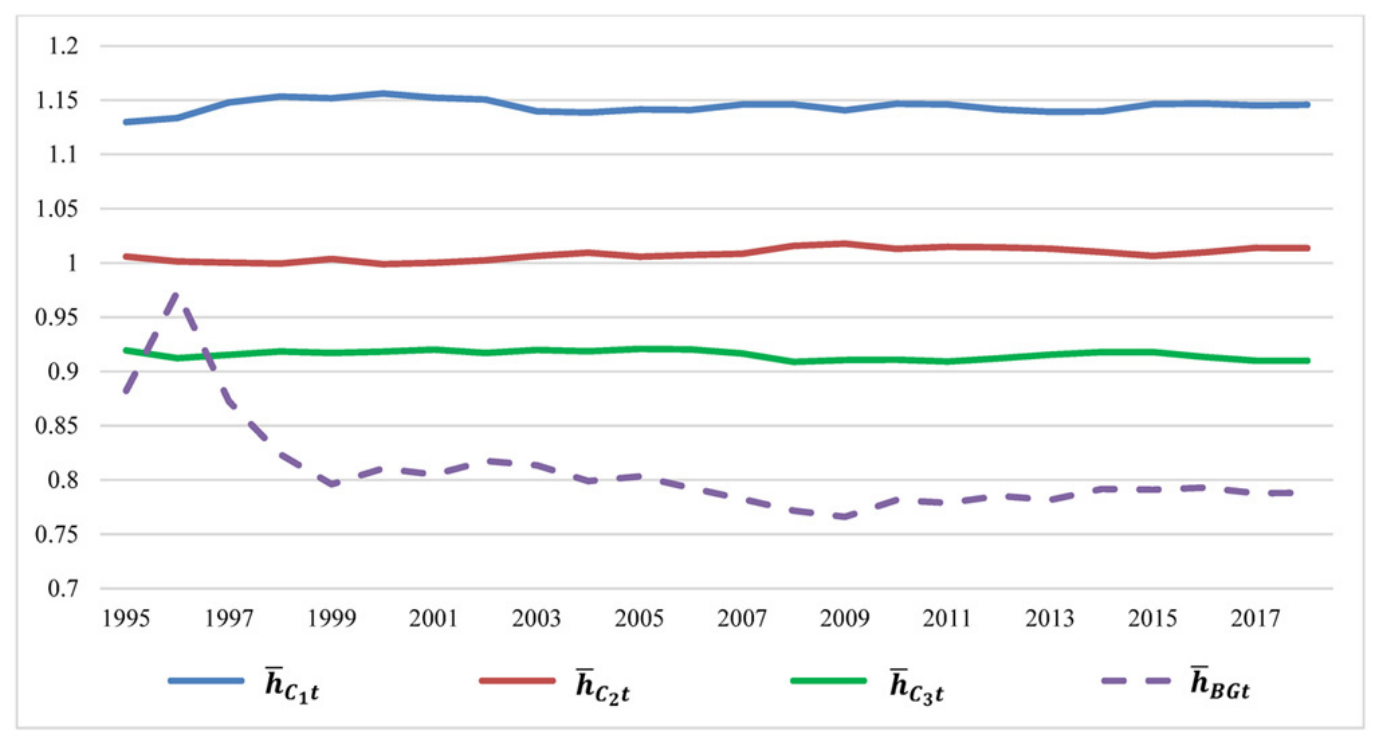

Notes. The transition curves plot the average transitions for each club, $\bar{h}_{C t}$ and the divergent countries' $h_{i t}$ over the period 1995-2018. Total Economy productivity is total GVA per-hour worked, PPP-adjusted constant 2015 Euro prices (Eurostat). Club 1: Belgium, Denmark, France, Germany, Ireland, Luxembourg. Club 2: Austria, Finland, Italy, Lithuania, Netherlands, Poland, Romania, Slovenia, Spain, Sweden, United Kingdom. Club 3: Croatia, Cyprus, Czechia, Estonia, Greece, Hungary, Latvia, Portugal, Slovakia. Divergent countries: Bulgaria (BG).

The evolution of the standard deviation, shown in Figure 2, confirms these patterns. Indeed, several authors suggest that countries' unresolved asymmetries explain the different responses to the global financial crisis and the end to the convergence process that mostly occurred in the first decade, up to 2007.

Figure 2. Standard deviation, total economy productivity, 1995-2018 


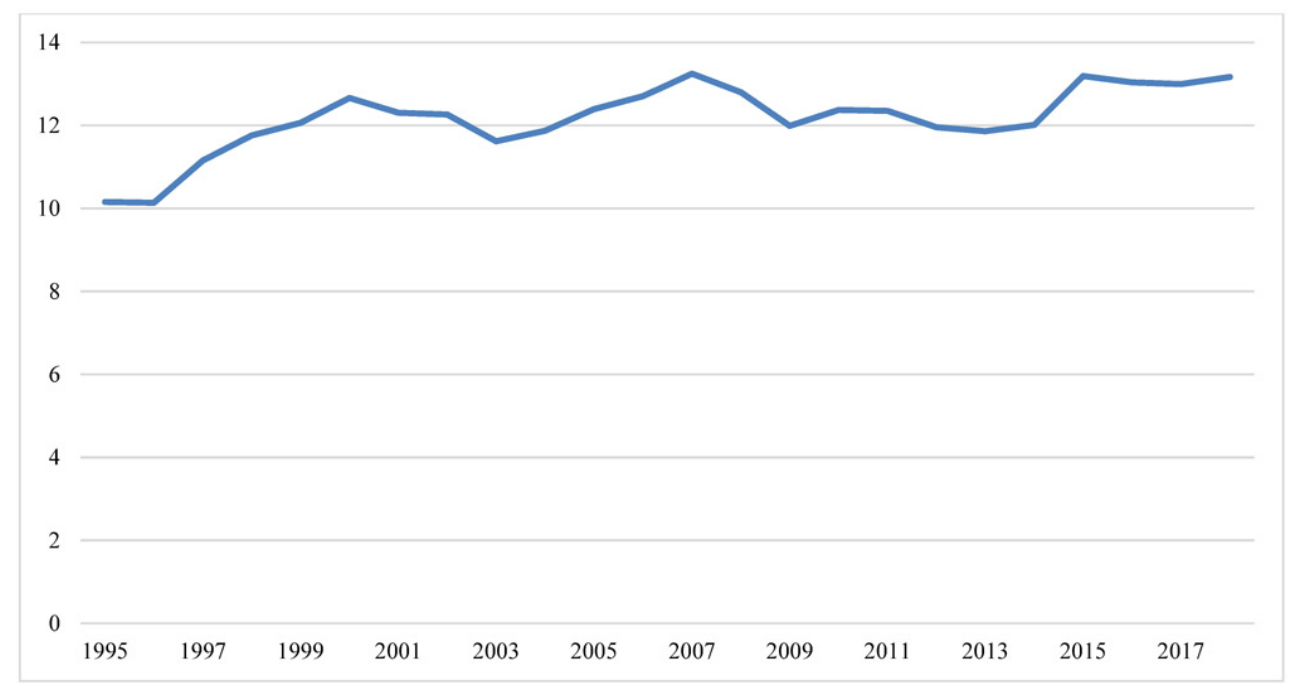

Notes. The curve plots the standard deviation of Total Economy productivity for 1995-2018. Total Economy productivity is total GVA per-hour worked, PPP-adjusted constant 2015 Euro prices (Eurostat).

Given this evidence, we focus on changes in the patterns of convergence in the more recent years in our sample period, after the economies adjusted to the global financial crisis. We mostly focus on the evolution of the convergence process following the developments in the aftermath of the global financial crisis and the implications for the asymptotical convergence patterns. If the original impetus to catch up is weakened, the club membership changes. The estimated convergence patterns for the more recent period can help us identify differences in countries' resilience and provide useful insights regarding unresolved asymmetries and the required policy actions. We therefore run the log- $t$ test for the period 2007-2018. The results are shown in Table 2.

As expected, when we exclude the years in which an intense period of successful catching up took place, we observe different growth convergence patterns among the EU economies. Over the shorter time span, cross-country differences are not smoothed out, leading to increased fragmentation, with five clubs and three diverging countries, based on the econometric test. The countries that were weakly members of Club 1 for the period 1995-2018 are now distributed into three clusters. Finland, Italy, Spain, Sweden, and the UK, which were initially grouped in Club 2, comprise Club 4 and approach an intermediate long-run path in the more recent subperiod. Finally, the remaining countries form Club 5 and approach a low-growth path. Figure 3 illustrates the distances between these convergence clubs based on the average transition paths $\bar{h}_{C_{s}}$. 
Table 2. Results of Log $t$ test for Productivity, Total Economy, 2007-2018

\begin{tabular}{|c|c|c|c|c|c|c|}
\hline & $\begin{array}{c}\text { No. of } \\
\text { Countries }\end{array}$ & $b$ & $T$-Stat & SE & $\begin{array}{l}\text { GVA phw } \\
2007 \\
\text { (Average) }\end{array}$ & $\begin{array}{l}\text { GVA phw } \\
2018 \\
\text { (Average) }\end{array}$ \\
\hline WHOLE SAMPLE & 27 & -0.7971 & -26.9268 & 0.0296 & 31.15 & 33.38 \\
\hline $\begin{array}{l}\text { Club } 1 \\
\text { Ireland, Luxembourg }\end{array}$ & 2 & 4.4784 & 3.7658 & 1.1892 & 56.71 & 64.26 \\
\hline $\begin{array}{l}\text { Club } 2 \\
\quad \text { Belgium, Denmark, France }\end{array}$ & 3 & 0.1023 & 2.0219 & 0.0506 & 42.94 & 46.24 \\
\hline $\begin{array}{l}\text { Club } 3 \\
\quad \text { Germany, Netherlands }\end{array}$ & 2 & 1.3520 & 4.1034 & 0.3295 & 43.81 & 43.72 \\
\hline $\begin{array}{l}\text { Club } 4 \\
\quad \text { Finland, Italy, Spain, Sweden, United } \\
\text { Kingdom }\end{array}$ & 5 & 0.3263 & 3.6542 & 0.0893 & 37.03 & 38.29 \\
\hline $\begin{array}{l}\text { Club } 5 \\
\text { Croatia, Cyprus, Czechia, Estonia, } \\
\text { Greece, Hungary, Latvia, Lithuania, } \\
\text { Poland, Portugal, Romania, Slovakia }\end{array}$ & 12 & 0.1008 & 1.3986 & 0.0721 & 20.42 & 22.55 \\
\hline $\begin{array}{l}\text { DIVERGENT } \\
\text { Austria, Bulgaria, Slovenia }\end{array}$ & 3 & -0.8076 & -22.3923 & 0.0361 & - & - \\
\hline
\end{tabular}

Notes. GVA phw is total GVA per-hour worked, current prices, purchasing power standards (Eurostat). Truncation parameter: $r=0.3$. Critical value: $c=0 . T$-Statistic at the $5 \%$ significance level: -1.645 .

Figure 3. Club average transition paths, $\bar{h}_{C t}$, total economy productivity, 2007-2018

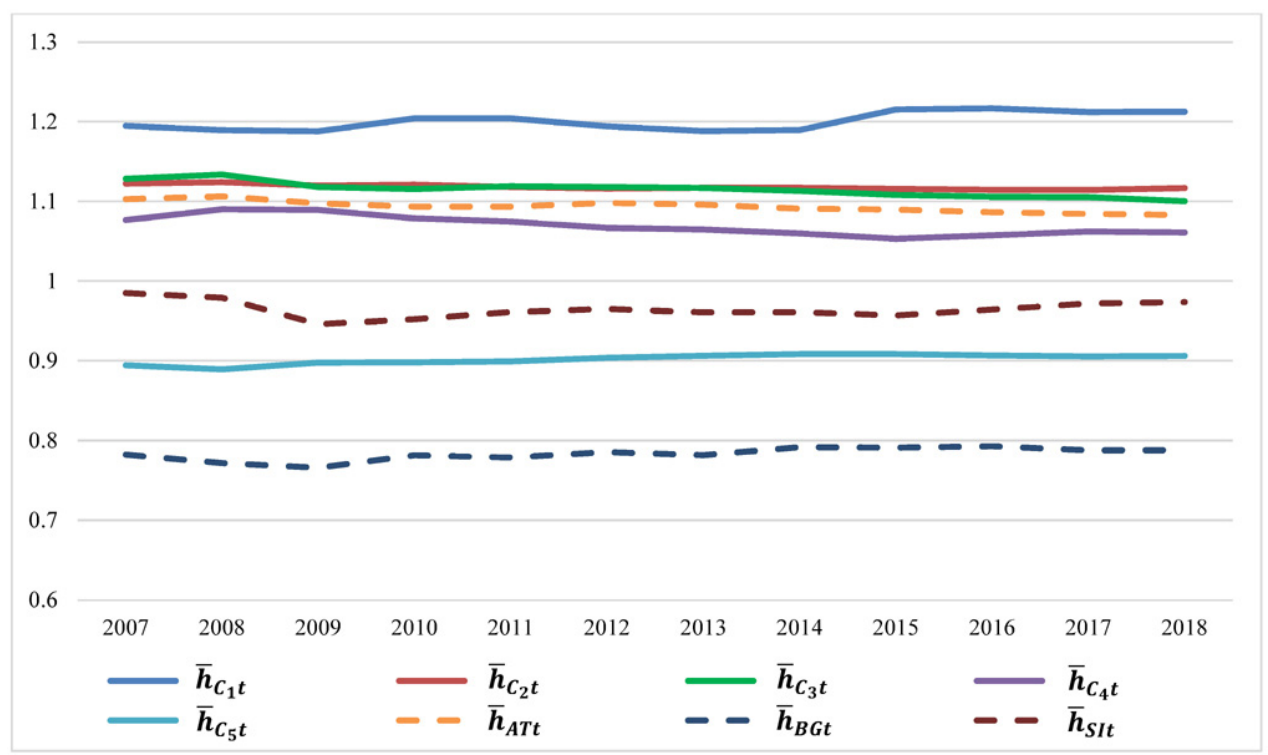

Notes. The transition curves plot the average transitions for each club, $\bar{h}_{C t}$ and the divergent countries' $h_{i t}$ over the period 2007-2018. Total Economy productivity is total GVA per-hour worked, PPP-adjusted constant 2015 Euro prices (Eurostat). Club 1: Ireland, Luxembourg. Club 2: Belgium, Denmark, France. Club 3: Germany, Netherlands. Club 4: Finland, Italy, Spain, Sweden, United Kingdom. Club 5: Croatia, Cyprus, Czechia, Estonia, Greece, Hungary, Latvia, Lithuania, Poland, Portugal, Romania, Slovakia. Divergent countries: Austria (AT), Bulgaria (BG), Slovenia (SI). 
The path of Club 1 (Ireland and Luxembourg) is well above the paths of the other clubs, whereas the transitions of Clubs 2 and 3 greatly overlap. Thus, the weak cohesion among Club 1 countries in the baseline regression (1995-2018) is mainly driven by the outperformance of these two offshore centers. Club 4's path is not very far from that of Club 3. The dotted line between Clubs 3 and 4 illustrates Austria's diverging dynamics, and that between Clubs 4 and 5 shows Slovenia's path. The average transition of Club 5 remains well below those of the other clubs, and Bulgaria's path is shown at the bottom of the graph.

The estimation results indicate a noticeable geographical polarization among the economic clusters, as shown in Figure 4.

Figure 4. Club membership, total economy productivity, 2008-2017

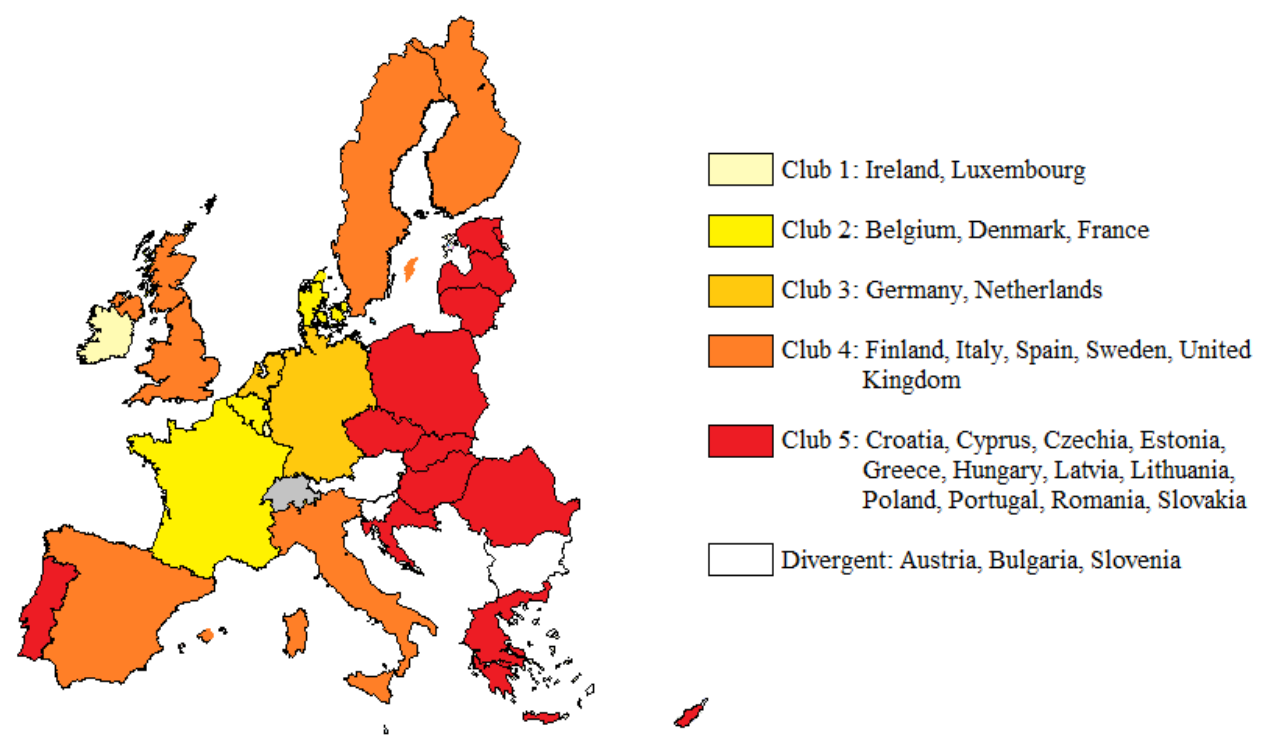

From left to right, the high-growth clusters in the northwestern EU are formed by Ireland and Luxembourg (Club 1); Belgium, Denmark, and France (Club 2); and Germany and the Netherlands (Club 3). Bordering this region is the intermediate-growth cluster formed by three nordic countries (i.e., the UK, Sweden, and Finland) and two southern countries (i.e., Italy and Spain). Moving towards the EU border, the low-growth cluster is formed by Portugal in the southwest, the Balkans (i.e., Croatia, Romania, Bulgaria, and Greece) in the peripheral southeastern region, and the Baltics at the northeastern frontier.

To further gain insight into the evolution of the convergence patterns, we also run a log- $t$ test for data from the period 1995-2006 for the EU27 countries. The results are given in Table A1 of the Appendix. Comparing the results for the two periods, a noticeable finding is that Greece, Slovakia, Slovenia, and Cyprus have remarkably worsened their positions, moving away 
from Italy, Spain, and the UK (Table A1) to the bottom group (Table 2). Austria, Finland, and Sweden have also shifted to lower positions, as they have detached from the leading group (i.e., Club 1 in Table A1). The remaining new EU member states are in the bottom clubs in both periods.

Finally, we run the log- $t$ test for a subsample containing just the old EU member states for the period 1995-2018 and compare the results to the baseline findings for the EU27. The results, reported in Table A2 of the Appendix, reveal similar clustering patterns to those in the baseline club classification, although the countries that form Club 4 in the full sample (Table 1) split into two groups in the subsample analysis (Table A2).

\section{Long-Run Growth in the EU: Real Per Capita Income Clubs at the Sector Level}

The convergence patterns at the aggregate level reflect structural asymmetries related to countries' specializations in terms of both the sectoral composition of total GVA and within-sector specializations in upstream or downstream production. As we mention earlier, related empirical studies commonly highlight that the new EU member states are generally tending to shift towards services, although the manufacturing sector is still very important. In particular, the manufacturing sector mainly contributes to the international diffusion of knowledge.

In Table 3, countries are grouped according to their club membership based on total economic productivity over 1995-2018 (see Table 1). The shading identifies the second-period clusters (see Table 2) reported in column 3. 
Table 3. Total Economy Convergence Clubs and Industry Shares

\begin{tabular}{|c|c|c|c|c|c|c|c|c|c|c|c|}
\hline & \multirow{2}{*}{ Countries } & \multicolumn{2}{|c|}{ CLUBS } & \multicolumn{8}{|c|}{ INDUSTRY SHARES } \\
\hline & & $1995-2018$ & $2007-2018$ & A & B-E & $\mathrm{F}$ & $\mathrm{C}$ & $\mathrm{h} / \mathrm{totC}$ & KIS & LKIS & $\mathrm{O}-\mathrm{U}$ \\
\hline \multirow{6}{*}{$\begin{array}{c}\text { CLUB } \\
1\end{array}$} & Ireland & 1 & 1 & 2.01 & 28.13 & 5.28 & 25.64 & 48.62 & 24.87 & 22.51 & 17.20 \\
\hline & Luxembourg & 1 & 1 & 0.51 & 9.93 & 5.83 & 8.19 & 3.87 & 40.96 & 25.99 & 16.78 \\
\hline & Belgium & 1 & 2 & 1.01 & 19.72 & 5.23 & 16.81 & 45.40 & 22.44 & 28.69 & 22.91 \\
\hline & Denmark & 1 & 2 & 1.85 & 19.89 & 5.18 & 14.89 & 48.47 & 17.54 & 29.67 & 25.87 \\
\hline & France & 1 & 2 & 2.02 & 16.16 & 5.46 & 13.51 & 39.64 & 21.59 & 30.02 & 24.75 \\
\hline & Germany & 1 & 3 & 0.97 & 25.43 & 4.76 & 22.33 & 57.36 & 20.12 & 27.06 & 21.66 \\
\hline & $A V G C L U B 1$ & & & 1.40 & 19.88 & 5.29 & 16.90 & 40.56 & 24.59 & 27.32 & 21.53 \\
\hline \multirow{11}{*}{$\begin{array}{c}\text { CLUB } \\
2\end{array}$} & Netherlands & 2 & 3 & 2.26 & 17.86 & 5.10 & 13.47 & 42.03 & 25.65 & 26.88 & 22.24 \\
\hline & Austria & 2 & DIV & 1.63 & 23.16 & 7.00 & 19.40 & 40.87 & 16.41 & 31.56 & 20.23 \\
\hline & Finland & 2 & 4 & 2.96 & 25.35 & 6.28 & 22.15 & 45.96 & 15.14 & 27.36 & 22.90 \\
\hline & Italy & 2 & 4 & 2.49 & 20.50 & 5.18 & 17.66 & 36.07 & 18.36 & 32.88 & 20.58 \\
\hline & Spain & 2 & 4 & 3.37 & 18.26 & 9.00 & 14.81 & 33.31 & 15.70 & 32.20 & 21.47 \\
\hline & Sweden & 2 & 4 & 2.00 & 22.24 & 5.27 & 18.59 & 39.08 & 20.22 & 26.65 & 23.62 \\
\hline & United Kingdom & 2 & 4 & 0.86 & 16.85 & 5.93 & 12.45 & 43.43 & 23.90 & 31.73 & 20.73 \\
\hline & Slovenia & 2 & DIV & 2.87 & 27.29 & 6.27 & 23.47 & 40.75 & 16.95 & 27.25 & 19.37 \\
\hline & Lithuania & 2 & 5 & 5.41 & 23.21 & 7.34 & 18.77 & 19.29 & 11.04 & 35.29 & 17.71 \\
\hline & Poland & 2 & 5 & 3.48 & 25.42 & 8.02 & 18.84 & 27.92 & 14.39 & 31.24 & 17.45 \\
\hline & Romania & 2 & 5 & 9.98 & 29.23 & 7.55 & 23.76 & 26.69 & 12.85 & 27.01 & 13.37 \\
\hline \multicolumn{4}{|c|}{$A V G C L U B 2$} & 3.39 & 22.67 & 6.63 & 18.49 & 35.95 & 17.33 & 30.01 & 19.97 \\
\hline \multirow{9}{*}{$\begin{array}{c}\text { CLUB } \\
3\end{array}$} & Croatia & 3 & 5 & 4.97 & 21.73 & 6.29 & 17.47 & 25.80 & 17.24 & 31.20 & 18.58 \\
\hline & Cyprus & 3 & 5 & 3.19 & 9.54 & 8.16 & 7.17 & 13.04 & 20.86 & 34.37 & 23.87 \\
\hline & Czechia & 3 & 5 & 2.75 & 31.13 & 6.44 & 25.25 & 42.55 & 14.92 & 27.64 & 17.12 \\
\hline & Estonia & 3 & 5 & 3.85 & 21.71 & 6.99 & 16.56 & 20.93 & 16.22 & 33.59 & 17.64 \\
\hline & Greece & 3 & 5 & 4.83 & 13.73 & 5.39 & 10.03 & 18.52 & 13.53 & 39.21 & 23.30 \\
\hline & Hungary & 3 & 5 & 5.16 & 25.95 & 4.79 & 22.22 & 48.37 & 17.32 & 26.09 & 20.69 \\
\hline & Latvia & 3 & 5 & 4.41 & 18.20 & 6.64 & 13.96 & 14.53 & 14.76 & 36.88 & 19.12 \\
\hline & Portugal & 3 & 5 & 2.99 & 18.70 & 6.11 & 15.15 & 22.18 & 16.46 & 32.83 & 22.91 \\
\hline & Slovakia & 3 & 5 & 2.44 & 26.59 & 7.17 & 21.15 & 34.34 & 15.40 & 30.70 & 17.70 \\
\hline \multicolumn{4}{|c|}{$A V G C L U B 3$} & 3.84 & 20.81 & 6.44 & 16.55 & 26.70 & 16.30 & 32.50 & 20.10 \\
\hline DIV & Bulgaria & DIV & DIV & 8.53 & 21.37 & 5.40 & 14.57 & 23.81 & 16.13 & 32.70 & 15.87 \\
\hline \multicolumn{4}{|c|}{$A V G E U$} & 3.29 & 21.38 & 6.22 & 17.34 & 33.44 & 18.55 & 30.34 & 20.21 \\
\hline
\end{tabular}

Notes. The table shows the industry shares (sectors A; B-E; F; C; h/TotC, i.e., High and Medium-High $\mathrm{C}$ as a share of Total C; KIS, i.e. J, K, M, N; LKIS, i.e. G-I, L; O-U) per country as well as per club, according to the 1995-2018 results of the $\log t$ test (see Table 1). Column one shows the EU27 countries ordered according to the 1995-2018 club membership in column two. Column three shows, for comparison purposes, the 2007-2018 club membership (see Table 2); columns four to eleven show the shares of the sectors considered to total economy.

The share of agriculture (A) is noticeably higher in the low-growth countries; specifically, this share is 3.84 percent in the bottom cluster but 1.4 percent in the top cluster. We find 
a similar pattern for the less knowledge-intensive sectors (LKIS), that is, the routine services, as low-growth countries have the highest shares on average.5) In contrast, the cross-country differences for industry (B-E) and construction (F) are not very relevant; although the intermediate group has the highest average shares for these sectors, several other countries have large shares as well. Within the industry (B-E) group, manufacturing (C) is important for almost all countries, but the heterogeneity in vertical specialization (High $\mathrm{C} /$ Total $\mathrm{C}$ ) is relevant. Innovation-intensive products are about $40 \%$ of all manufactured goods on average in high-income countries but are slightly above $25 \%$ of manufactured goods in low-income countries. Importantly, Lithuania, Poland, and Romania, which shift from intermediate-growth to low-growth clusters after the global financial crisis (column 3), have relatively low shares of innovation-intensive products. The Czech Republic, Hungary, and Slovakia, in contrast, have higher shares of innovation-intensive manufactured products. All of the other countries in Club 5 have the lowest shares of knowledge-intensive services (KIS).

Overall, the countries with relatively low shares of innovation-intensive products or knowledge-intensive services fail to fully catch up with the more advanced EU countries. Indeed, the CEECs that have successfully integrated into the global production networks of the Central European Manufacturing Core (Becker et al., 2010; Landesmann \& Stöllinger, 2019; Stehrer $\&$ Stöllinger, 2014) still fall behind in the knowledge-intensive services. The remaining countries in Club 5 have not modernized the productive structures of their economies and have excessive shares of agriculture and routine services, which are notoriously characterized by lower productivity growth.

To analyze the features of countries' vertical specializations in more depth, we apply the PS methodology to the sectoral data. Table 4 shows the results of the log- $t$ test for sectors. This convergence analysis supports the overall results at the aggregate level. The $27 \mathrm{EU}$ countries do not approach a common productivity growth path in any of the seven sectors, as the $T$-Stat value for the full panel is below the threshold value of -1.65 for all sectors.

5) Following Eurostat, we divide services (i.e., the NACE2 sectors and subsectors) into knowledge-intensive services (KIS) and less knowledge-intensive (i.e., routine) services (LKIS). This division is analogous to that in the manufacturing sector. See https://ec.europa.eu/eurostat/cache/metadata/Annexes/htec_esms_an3.pdf. 
Table 4. Results of Log $t$ test for Sectoral Productivity, 1995-2018

Table 4a. Agriculture, Forestry and Fishing (A)

\begin{tabular}{|c|c|c|c|c|c|c|}
\hline & $\begin{array}{l}\text { No. of } \\
\text { Countries }\end{array}$ & $b$ & $T$-Stat & SE & $\begin{array}{l}\text { GVA phw } \\
1995 \\
\text { (Average) }\end{array}$ & $\begin{array}{l}\text { GVA phw } \\
2018 \\
\text { (Average) }\end{array}$ \\
\hline WHOLE SAMPLE & 27 & -0.4022 & -10.8341 & 0.0371 & 9.44 & 14.27 \\
\hline $\begin{array}{l}\text { Club } 1 \\
\text { Austria, Belgium, Croatia, Czechia, Denmark, } \\
\text { Estonia, Finland, France, Germany, Greece, } \\
\text { Hungary, Ireland, Italy, Latvia, Lithuania, } \\
\text { Luxembourg, Netherlands, Portugal, Slovakia, } \\
\text { Slovenia, Spain, Sweden, United Kingdom }\end{array}$ & 23 & -0.0271 & -0.5590 & 0.0484 & 9.92 & 15.63 \\
\hline $\begin{array}{l}\text { Club } 2 \\
\quad \text { Bulgaria, Cyprus, Poland, Romania }\end{array}$ & 4 & 0.3604 & 4.4527 & 0.0809 & 6.67 & 6.42 \\
\hline \multicolumn{7}{|l|}{$\begin{array}{l}\text { Notes. GVA phw is sectoral GVA per-hour worked } \\
\text { Truncation parameter: } r=0.3 \text {. Critical valu } \\
\text { Table 4b. Industry, Excluding Construction (B-E) }\end{array}$} \\
\hline & $\begin{array}{l}\text { No. of } \\
\text { Countries }\end{array}$ & $b$ & $T$-Stat & SE & $\begin{array}{l}\text { GVA phw } \\
1995 \\
\text { (Average) }\end{array}$ & $\begin{array}{l}\text { GVA phw } \\
2018 \\
\text { (Average) }\end{array}$ \\
\hline WHOLE SAMPLE & 27 & -0.7507 & -108.5832 & 0.0069 & 25.85 & 46.17 \\
\hline $\begin{array}{l}\text { Club } 1 \\
\quad \text { Denmark, Netherlands }\end{array}$ & 2 & -0.0598 & -0.0285 & 2.0952 & 41.53 & 70.59 \\
\hline $\begin{array}{l}\text { Club } 2 \\
\quad \text { Austria, Belgium, Finland, France, Germany, } \\
\text { Poland, Spain, Sweden, United Kingdom }\end{array}$ & 9 & -0.0691 & -1.0402 & 0.0664 & 29.99 & 53.37 \\
\hline $\begin{array}{l}\text { Club } 3 \\
\text { Croatia, Cyprus, Czechia, Estonia, Greece, } \\
\text { Hungary, Italy, Latvia, Lithuania, Luxembourg, } \\
\text { Portugal, Romania, Slovakia, Slovenia }\end{array}$ & 14 & 0.0266 & 1.0181 & 0.0261 & 20.42 & 28.79 \\
\hline $\begin{array}{l}\text { DIVERGENT } \\
\text { Bulgaria, Ireland }\end{array}$ & 2 & -1.3436 & -201.6701 & 0.0067 & - & - \\
\hline
\end{tabular}

Notes. GVA phw is sectoral GVA per-hour worked (sectors B-E), current prices, purchasing power standards (Eurostat). Truncation parameter: $r=0.3$. Critical value: $c=0$. T-Statistic at the $5 \%$ significance level: -1.645 .

Table 4c. Construction (F)

\begin{tabular}{|c|c|c|c|c|c|c|}
\hline & $\begin{array}{l}\text { No. of } \\
\text { Countries }\end{array}$ & $b$ & $T$-Stat & SE & $\begin{array}{l}\text { GVA phw } \\
1995 \\
\text { (Average) }\end{array}$ & $\begin{array}{l}\text { GVA phw } \\
2018 \\
\text { (Average) }\end{array}$ \\
\hline WHOLE SAMPLE & 27 & -0.7056 & -31.3751 & 0.0225 & 23.41 & 24.31 \\
\hline $\begin{array}{l}\text { Club } 1 \\
\text { Austria, Belgium, Denmark, Estonia, France, } \\
\text { Germany, Ireland, Lithuania, Luxembourg, } \\
\text { Netherlands, Spain, Sweden, United Kingdom }\end{array}$ & 13 & 0.1332 & 1.3044 & 0.1021 & 27.75 & 30.98 \\
\hline $\begin{array}{l}\text { Club } 2 \\
\text { Croatia, Cyprus, Finland, Italy, Latvia, } \\
\text { Poland, Portugal, Slovakia, Slovenia }\end{array}$ & 9 & -0.0285 & -0.6667 & 0.0428 & 21.60 & 20.70 \\
\hline $\begin{array}{l}\text { Club } 3 \\
\text { Czechia, Romania }\end{array}$ & 2 & 0.6730 & 0.3280 & 2.0518 & 22.68 & 15.18 \\
\hline $\begin{array}{l}\text { DIVERGENT } \\
\text { Bulgaria, Greece, Hungary }\end{array}$ & 3 & -1.9938 & -10.2378 & 0.1947 & - & - \\
\hline
\end{tabular}

Notes. GVA phw is sectoral GVA per-hour worked (sector F), current prices, purchasing power standards (Eurostat). Truncation parameter: $r=0.3$. Critical value: $c=0$. T-Statistic at the $5 \%$ significance level: -1.645 . 
Table 4. Continued

Table 4d. Manufacturing (C)

\begin{tabular}{|c|c|c|c|c|c|c|}
\hline & $\begin{array}{c}\text { No. of } \\
\text { Countries }\end{array}$ & $b$ & $T$-Stat & $\mathrm{SE}$ & $\begin{array}{c}\text { GVA phw } \\
1995 \\
\text { (Average) }\end{array}$ & $\begin{array}{c}\text { GVA phw } \\
2018 \\
\text { (Average) }\end{array}$ \\
\hline WHOLE SAMPLE & 27 & -0.6814 & -115.2718 & 0.0059 & 21.45 & 43.02 \\
\hline $\begin{array}{l}\text { Club } 1 \\
\text { Austria, Belgium, Denmark, Finland, France, } \\
\text { Germany, Lithuania, Netherlands, Poland, } \\
\text { Slovakia, Sweden, United Kingdom }\end{array}$ & 12 & 0.1531 & 2.5231 & 0.0607 & 23.84 & 48.09 \\
\hline $\begin{array}{l}\text { Club } 2 \\
\text { Croatia, Czechia, Estonia, Greece, Hungary, } \\
\text { Italy, Luxembourg, Portugal, Romania, } \\
\text { Slovenia, Spain }\end{array}$ & 11 & 0.1158 & 3.6905 & 0.0314 & 19.52 & 29.01 \\
\hline $\begin{array}{l}\text { Club } 3 \\
\quad \text { Bulgaria, Cyprus, Latvia }\end{array}$ & 3 & 0.8459 & 8.2853 & 0.1021 & 12.19 & 16.26 \\
\hline $\begin{array}{l}\text { DIVERGENT } \\
\text { Ireland }\end{array}$ & 1 & - & - & - & - & - \\
\hline
\end{tabular}

Notes. GVA phw is sectoral GVA per-hour worked (sector C), current prices, purchasing power standards (Eurostat). Truncation parameter: $r=0.3$. Critical value: $c=0$. T-Statistic at the 5\% significance level: -1.645 .

Table 4e. KIS (J, K, M, N)

\begin{tabular}{|c|c|c|c|c|c|c|}
\hline & $\begin{array}{l}\text { No. of } \\
\text { Countries }\end{array}$ & $b$ & $T$-Stat & $\mathrm{SE}$ & $\begin{array}{l}\text { GVA phw } \\
1995 \\
\text { (Average) }\end{array}$ & $\begin{array}{l}\text { GVA phw } \\
2018 \\
\text { (Average) }\end{array}$ \\
\hline WHOLE SAMPLE & 27 & -1.4747 & -46.3977 & 0.0318 & 40.53 & 39.75 \\
\hline $\begin{array}{l}\text { Club } 1 \\
\quad \text { Ireland, Luxembourg, Sweden }\end{array}$ & 3 & 0.2510 & 5.3775 & 0.0467 & 65.91 & 81.97 \\
\hline $\begin{array}{l}\text { Club } 2 \\
\text { Austria, Belgium, Cyprus, Denmark, France, } \\
\text { Germany, Netherlands, Romania, United } \\
\text { Kingdom }\end{array}$ & 9 & 0.1916 & 1.6666 & 0.1150 & 39.70 & 43.76 \\
\hline $\begin{array}{l}\text { Club } 3 \\
\text { Croatia, Czechia, Estonia, Finland, Italy, } \\
\text { Poland, Slovakia, Spain }\end{array}$ & 8 & 0.1316 & 7.0490 & 0.0187 & 37.09 & 32.74 \\
\hline $\begin{array}{l}\text { Club } 4 \\
\quad \text { Bulgaria, Greece, Hungary, Latvia, Lithuania, } \\
\text { Portugal, Slovenia }\end{array}$ & 7 & 0.8487 & 3.3578 & 0.2528 & 34.66 & 24.49 \\
\hline
\end{tabular}

Notes. GVA phw is sectoral GVA per-hour worked (sectors J, K, M, N), current prices, purchasing power standards (Eurostat). Truncation parameter: $r=0.3$. Critical value: $c=0 . T$-Statistic at the $5 \%$ significance level: -1.645 . 
Table 4. Continued

Table 4f. LKIS (G-I, L)

\begin{tabular}{|c|c|c|c|c|c|c|}
\hline & $\begin{array}{l}\text { No. of } \\
\text { Countries }\end{array}$ & $b$ & $T$-Stat & SE & $\begin{array}{l}\text { GVA phw } \\
1995 \\
\text { (Average) }\end{array}$ & $\begin{array}{l}\text { GVA phw } \\
2018 \\
\text { (Average) }\end{array}$ \\
\hline WHOLE SAMPLE & 27 & -0.7628 & -23.1011 & 0.0330 & 32.67 & 37.60 \\
\hline $\begin{array}{l}\text { Club } 1 \\
\text { Austria, Belgium, Denmark, Finland, } \\
\text { France, Germany, Luxembourg, } \\
\text { Netherlands, United Kingdom }\end{array}$ & 9 & 0.0384 & 0.9944 & 0.0386 & 40.42 & 52.70 \\
\hline $\begin{array}{l}\text { Club } 2 \\
\quad \text { Ireland, Italy, Spain, Sweden }\end{array}$ & 4 & 0.1012 & 0.6531 & 0.1550 & 39.18 & 43.09 \\
\hline $\begin{array}{l}\text { Club } 3 \\
\text { Croatia, Cyprus, Czechia, Estonia, Greece, } \\
\text { Hungary, Latvia, Lithuania, Poland, } \\
\text { Portugal, Romania, Slovakia, Slovenia }\end{array}$ & 13 & 0.0628 & 2.9048 & 0.0216 & 25.33 & 26.97 \\
\hline $\begin{array}{l}\text { DIVERGENT } \\
\text { Bulgaria }\end{array}$ & 1 & - & - & - & - & - \\
\hline \multicolumn{7}{|l|}{$\begin{array}{l}\text { Notes. GVA phw is sectoral GVA } \\
\text { Truncation parameter: } r= \\
\text { Table 4g. Other Services }(\mathrm{O}-\mathrm{U})\end{array}$} \\
\hline & $\begin{array}{c}\text { No. of } \\
\text { Countries }\end{array}$ & $b$ & $T$-Stat & SE & $\begin{array}{l}\text { GVA phw } \\
1995 \\
\text { (Average) }\end{array}$ & $\begin{array}{l}\text { GVA phw } \\
2018 \\
\text { (Average) }\end{array}$ \\
\hline WHOLE SAMPLE & 27 & -0.5657 & -18.2758 & 0.0310 & 23.34 & 25.48 \\
\hline $\begin{array}{l}\text { Club } 1 \\
\text { Austria, Belgium, Denmark, Finland, France, } \\
\text { Germany, Ireland, Italy, Luxembourg, } \\
\text { Netherlands, Romania, Spain, United Kingdom }\end{array}$ & 14 & -0.0862 & -1.2361 & 0.0697 & 28.49 & 32.34 \\
\hline $\begin{array}{l}\text { Club } 2 \\
\text { Bulgaria, Croatia, Cyprus, Czechia, Estonia, } \\
\text { Greece, Hungary, Latvia, Lithuania, Poland, } \\
\text { Portugal, Slovakia, Slovenia }\end{array}$ & 13 & 0.0381 & 0.6419 & 0.0593 & 17.80 & 18.09 \\
\hline
\end{tabular}

Notes. GVA phw is sectoral GVA per-hour worked (sectors O-U), current prices, purchasing power standards (Eurostat). Truncation parameter: $r=0.3$. Critical value: $c=0$. T-Statistic at the 5\% significance level: -1.645 .

The patterns of the convergence clubs do vary by sector. We find two clusters for agriculture (A) and other services (O-U), four clusters for the knowledge-intensive services (KIS), and three clusters with many diverging countries for the remaining sectors. To summarize, we generally confirm that the old EU member states that are forging ahead mostly cluster in the top clubs and approach higher productivity growth paths in the long run. In line with the specialization patterns highlighted in Table 3, the more dynamic CEECs hold relatively favorable positions in manufacturing (C), with Lithuania, Poland, and Slovakia belonging to Club 1 along with 
the countries that approach the higher productivity growth path. However, these countries hold rather disadvantaged positions in the knowledge intensive services, with Poland and Slovakia grouped in Club 3 and Lithuania in Club 4, with Romania being a noticeable exception. Structural weakness in the routine services (LKIS) is common to all the new EU member states.

To gain insights into the evolution of the sectoral productivity convergence patterns, we run log- $t$ tests for the period of 2007-2018. The results for manufacturing (C), knowledge-intensive services (KIS), and routine services (LKIS) are reported in Table 5.6)

The econometric analyses by sector confirm the increased fragmentation in the post-crisis period found for the overall economy. The average productivity level in knowledge-intensive services (KIS) is noticeably lower in 2018 than in 2007 for countries in Clubs 3, 4, and 5 (Table 5c). Comparing countries' club memberships in the baseline period and the post-crisis sub-period, we find that the number of clubs increases for both manufacturing (C) and routine services (LKIS) and that several countries follow diverging paths in the knowledge-intensive services (KIS). Notably, Lithuania, Poland, and Slovakia evolve unfavorably in the manufacturing sector.

Table 5. Results of Log $t$ test for Sectoral Productivity, 2007-2018

Table 5a. Manufacturing (C)

\begin{tabular}{|c|c|c|c|c|c|c|}
\hline & $\begin{array}{l}\text { No. of } \\
\text { Countries }\end{array}$ & $b$ & $T$-Stat & SE & $\begin{array}{l}\text { GVA phw } \\
2007 \\
\text { (Average) }\end{array}$ & $\begin{array}{l}\text { GVA phw } \\
2018 \\
\text { (Average) }\end{array}$ \\
\hline WHOLE SAMPLE & 27 & -1.0125 & -67.4371 & 0.0150 & 33.23 & 43.02 \\
\hline $\begin{array}{l}\text { Club } 1 \\
\text { Belgium, Denmark }\end{array}$ & 2 & -0.9001 & -0.4125 & 2.1824 & 48.57 & 62.48 \\
\hline $\begin{array}{l}\text { Club } 2 \\
\quad \text { Austria, France, Germany, Netherlands }\end{array}$ & 4 & 1.3011 & 4.8852 & 0.2663 & 49.45 & 56.16 \\
\hline $\begin{array}{l}\text { Club } 3 \\
\quad \text { Finland, Italy, Luxembourg, Slovakia, } \\
\text { Spain, Sweden, United Kingdom }\end{array}$ & 7 & -0.0336 & -0.3954 & 0.0851 & 40.93 & 43.41 \\
\hline $\begin{array}{l}\text { Club } 4 \\
\text { Czechia, Greece, Hungary, Lithuania, } \\
\text { Poland, Romania, Slovenia }\end{array}$ & 7 & 0.1253 & 1.5959 & 0.0785 & 20.56 & 26.49 \\
\hline $\begin{array}{l}\text { Club } 5 \\
\qquad \text { Croatia, Estonia, Latvia, Portugal }\end{array}$ & 4 & -0.0917 & -0.9564 & 0.0958 & 15.77 & 18.64 \\
\hline $\begin{array}{l}\text { Club } 6 \\
\text { Bulgaria, Cyprus }\end{array}$ & 2 & 0.3856 & 3.6471 & 0.1057 & 14.41 & 15.76 \\
\hline $\begin{array}{l}\text { DIVERGENT } \\
\text { Ireland }\end{array}$ & 1 & - & - & - & - & - \\
\hline
\end{tabular}

Notes. GVA phw is sectoral GVA per-hour worked (sector C), current prices, purchasing power standards (Eurostat). Truncation parameter: $r=0.3$. Critical value: $c=0$. T-Statistic at the $5 \%$ significance level: -1.645 .

6) The results for the remaining sectors are available upon request. 
Table 5. Continued

Table 5b. KIS (J, K, M, N)

\begin{tabular}{|c|c|c|c|c|c|c|}
\hline & $\begin{array}{l}\text { No. of } \\
\text { Countries }\end{array}$ & $b$ & $T$-Stat & SE & $\begin{array}{l}\text { GVA phw } \\
2007 \\
\text { (Average) }\end{array}$ & $\begin{array}{l}\text { GVA phw } \\
2018 \\
\text { (Average) }\end{array}$ \\
\hline WHOLE SAMPLE & 27 & -1.4069 & -278.8538 & 0.0050 & 41.95 & 39.75 \\
\hline $\begin{array}{l}\text { Club } 1 \\
\quad \text { Ireland, Luxembourg }\end{array}$ & 2 & 4.0465 & 2.5265 & 1.6016 & 84.00 & 92.64 \\
\hline $\begin{array}{l}\text { Club } 2 \\
\quad \text { Belgium, Cyprus, France, Netherlands, } \\
\text { Poland, Romania, United Kingdom }\end{array}$ & 7 & 0.0081 & 0.1086 & 0.0743 & 39.26 & 41.62 \\
\hline $\begin{array}{l}\text { Club } 3 \\
\quad \text { Croatia, Czechia, Estonia, Slovakia }\end{array}$ & 4 & 0.3888 & 0.6969 & 0.5580 & 36.02 & 29.44 \\
\hline $\begin{array}{l}\text { Club } 4 \\
\text { Bulgaria, Hungary, Slovenia }\end{array}$ & 3 & 0.1663 & 0.4763 & 0.3492 & 28.47 & 26.42 \\
\hline $\begin{array}{l}\text { Club } 5 \\
\text { Lithuania, Portugal }\end{array}$ & 2 & 1.6573 & 0.9438 & 1.7560 & 33.14 & 23.44 \\
\hline $\begin{array}{l}\text { DIVERGENT } \\
\text { Austria, Denmark, Finland, Germany, } \\
\text { Greece, Italy, Latvia, Spain, Sweden }\end{array}$ & 9 & -1.5574 & -188.2932 & 0.0083 & - & - \\
\hline
\end{tabular}

Notes. GVA phw is sectoral GVA per-hour worked (sectors $\mathrm{J}, \mathrm{K}, \mathrm{M}, \mathrm{N}$ ), current prices, purchasing power standards (Eurostat). Truncation parameter: $r=0.3$. Critical value: $c=0$. $T$-Statistic at the $5 \%$ significance level: -1.645 .

Table 5c. LKIS (G-I, L)

\begin{tabular}{|c|c|c|c|c|c|c|}
\hline & $\begin{array}{l}\text { No. of } \\
\text { Countries }\end{array}$ & $b$ & $T$-Stat & SE & $\begin{array}{l}\text { GVA phw } \\
2007 \\
\text { (Average) }\end{array}$ & $\begin{array}{l}\text { GVA phw } \\
2018 \\
\text { (Average) }\end{array}$ \\
\hline WHOLE SAMPLE & 27 & -0.7442 & -21.0849 & 0.0353 & 35.31 & 37.60 \\
\hline $\begin{array}{l}\text { Club } 1 \\
\text { Belgium, Denmark, Luxembourg }\end{array}$ & 3 & 0.2791 & 2.0940 & 0.1333 & 58.16 & 59.01 \\
\hline $\begin{array}{l}\text { Club } 2 \\
\quad \text { Austria, Finland, Ireland, Italy, Netherlands, } \\
\text { Spain, Sweden, United Kingdom }\end{array}$ & 8 & 0.0922 & 1.0816 & 0.0852 & 42.66 & 45.49 \\
\hline $\begin{array}{l}\text { Club } 3 \\
\quad \text { Cyprus, Latvia, Lithuania, Poland, Portugal }\end{array}$ & 5 & 0.2188 & 2.3441 & 0.0934 & 23.20 & 27.88 \\
\hline $\begin{array}{l}\text { Club } 4 \\
\text { Croatia, Czechia, Estonia, Greece, } \\
\text { Hungary, Romania, Slovakia }\end{array}$ & 7 & 0.7480 & 4.5369 & 0.1649 & 23.95 & 24.88 \\
\hline $\begin{array}{l}\text { DIVERGENT } \\
\text { Bulgaria, France, Germany, Slovenia }\end{array}$ & 4 & -0.9536 & -33.8421 & 0.0282 & - & - \\
\hline
\end{tabular}

Notes. GVA phw is sectoral GVA per-hour worked (sectors G-I, L), current prices, purchasing power standards (Eurostat). Truncation parameter: $r=0.3$. Critical value: $c=0$. T-Statistic at the $5 \%$ significance level: -1.645 .

The average transitional dynamics for the clubs in manufacturing, knowledge-intensive services, and routine services are depicted in Figures 5, 6, and 7, respectively. The figures provide insights on the distances between the clusters and the positions of the diverging economies with respect to the convergence clubs (dotted curves). 
Figure 5. Club average transition paths, $\bar{h}_{C t}$, manufacturing productivity, 2007-2018

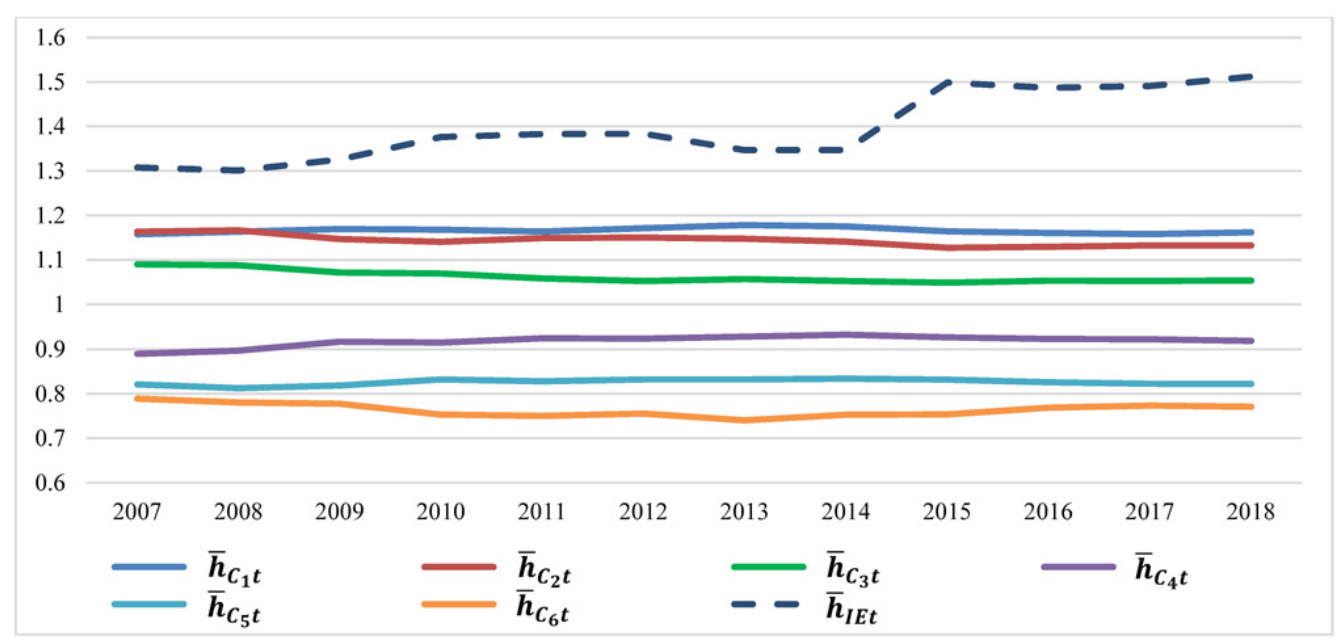

Notes. The transition curves plot the average transitions for each club, $\bar{h}_{C t}$ and the divergent countries' $h_{i t}$ over the period 2007-2018. Manufacturing productivity is GVA per-hour worked for the Manufacturing sector, PPP-adjusted constant 2015 Euro prices (Eurostat). Club 1: Belgium, Denmark. Club 2: Austria, France, Germany, Netherlands. Club 3: Finland, Italy, Luxembourg, Slovakia, Spain, Sweden, United Kingdom. Club 4: Czechia, Greece, Hungary, Lithuania, Poland, Romania, Slovenia. Club 5: Croatia, Estonia, Latvia, Portugal. Club 6: Bulgaria, Cyprus. Divergent countries: Ireland (IE).

In the manufacturing sector, Ireland clearly diverges upwards from the beginning of the period. The paths of Clubs 1 and 2 remain very close, with Club 3 slightly below Clubs 1 and 2, as these three clusters derive from the splitting of the original Club 1. The other three paths show the relative positions of the new EU member states, with the exception of Slovakia, which is in Club 3. The countries that are integrated into the core manufacturing group are better positioned but are still distant from the old EU member states.

For the knowledge-intensive services, countries' relative positions are in line with those observed for the full period of 1995-2018, although they are more fragmented. Sweden diverges from the common long-run growth path of Ireland and Luxembourg, which keep forging ahead; Denmark and Germany diverge upwards from Club 2; the paths of Finland, Austria, and Italy stay very close and right below Club 2; and Spain's long-run path is more distant but still clearly above the average transition for Club 3.

The graph of Figure 6 provides evidence of the long-run productivity gaps faced by the remaining countries, especially those in Clubs 4 and 5 and the two diverging countries, Latvia and Greece.

Finally, in the routine services sector, France and Germany fall between the paths of Clubs 1 and 2, with Slovenia below these clubs. The dynamic paths of the countries that are falling behind are clearly even further below. 
Figure 6. Club average transition paths, $\bar{h}_{C t}$, KIS productivity, 2007-2018

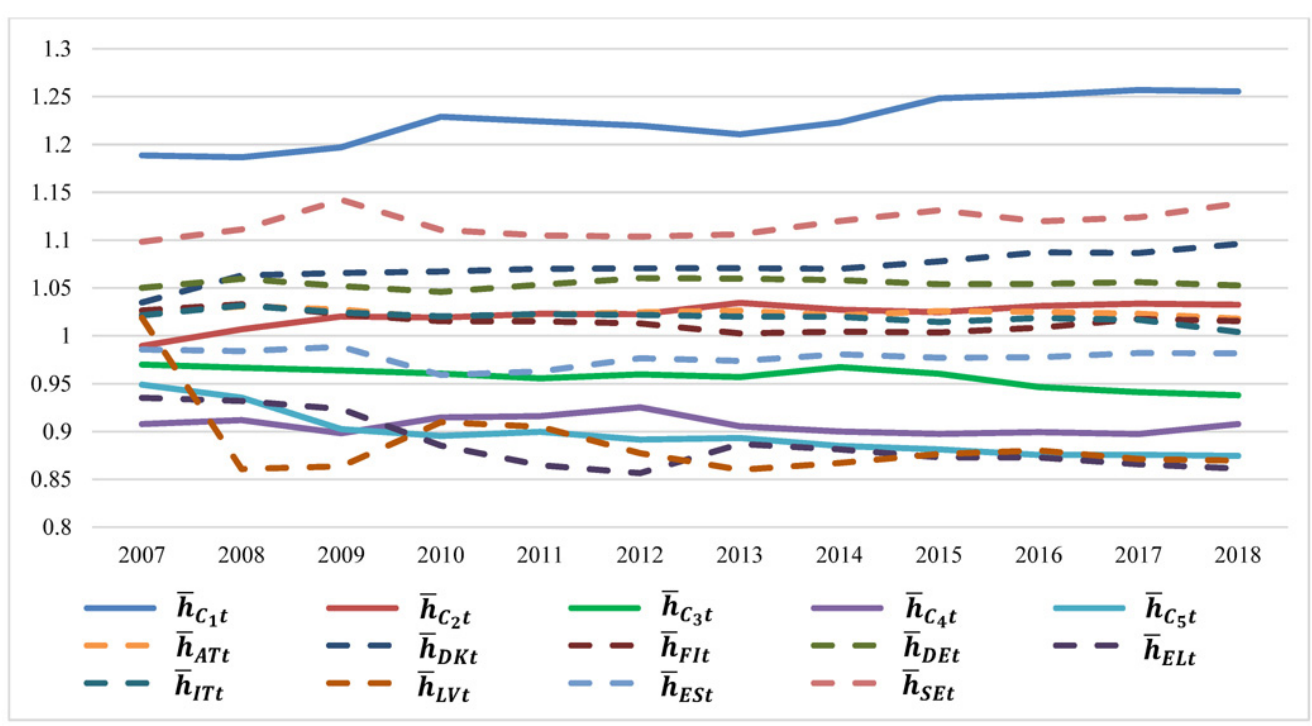

Notes. The transition curves plot the average transitions for each club, $\bar{h}_{C t}$ and the divergent countries' $h_{i t}$ over the period 2007-2018. KIS productivity is GVA per-hour worked for the KIS sectors, PPP-adjusted constant 2015 Euro prices (Eurostat). Club 1: Ireland, Luxembourg. Club 2: Belgium, Cyprus, France, Netherlands, Poland, Romania, United Kingdom. Club 3: Croatia, Czechia, Estonia, Slovakia. Club 4: Bulgaria, Hungary, Slovenia. Club 5: Lithuania, Portugal. Divergent countries: Austria (AT), Denmark (DK), Finland (FI), Germany (DE), Greece (EL), Italy (IT), Latvia (LV), Spain (ES), Sweden (SE).

Figure 7. Club average transition paths, $\bar{h}_{C t}$, LKIS productivity, 2007-2018

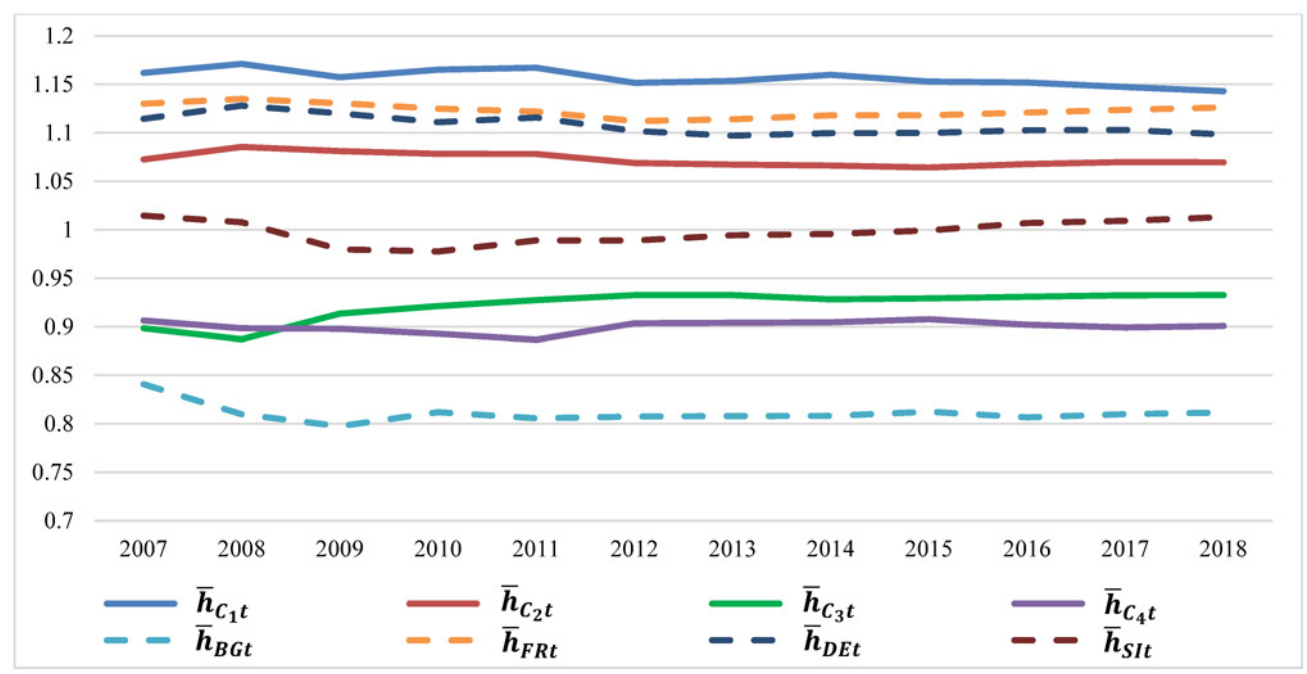

Notes. The transition curves plot the average transitions for each club, $\bar{h}_{C t}$ and the divergent countries' $h_{i t}$ over the period 2007-2018. LKIS productivity is GVA per-hour worked for the LKIS sectors, PPP-adjusted constant 2015 Euro prices (Eurostat). Club 1: Belgium, Denmark, Luxembourg. Club 2: Austria, Finland, Ireland, Italy, Netherlands, Spain, Sweden, United Kingdom. Club 3: Cyprus, Latvia, Lithuania, Poland, Portugal. Club 4: Croatia, Czechia, Estonia, Greece, Hungary, Romania, Slovakia. Divergent countries: Bulgaria (BG), France (FR), Germany (DE), Slovenia (SI). 
Overall, the estimated sector-level convergence patterns provide an explanation for the aggregate-level convergence patterns. Table 6 summarizes the results for the total economy (column 1), manufacturing (column 2), knowledge-intensive services (column 3), and routine services (column 4) over the period 2007-2018.

Table 6. Total Economy and Sectoral Convergence Clubs, 2007-2018

\begin{tabular}{|c|c|c|c|c|}
\hline Countries & Clubs - Tot & Clubs -Manufacturing & Clubs - KIS & Clubs - LKIS \\
\hline Ireland & 1 & DIV & 1 & 2 \\
\hline Luxembourg & 1 & 3 & 1 & 1 \\
\hline Denmark & 2 & 1 & DIV & 1 \\
\hline Belgium & 2 & 1 & 2 & 1 \\
\hline France & 2 & 2 & 2 & DIV \\
\hline Germany & 3 & 2 & DIV & DIV \\
\hline Netherlands & 3 & 2 & 2 & 2 \\
\hline Austria & DIV & 2 & DIV & 2 \\
\hline Finland & 4 & 3 & DIV & 2 \\
\hline Italy & 4 & 3 & DIV & 2 \\
\hline Spain & 4 & 3 & DIV & 2 \\
\hline Sweden & 4 & 3 & DIV & 2 \\
\hline United Kingdom & 4 & 3 & 2 & 2 \\
\hline Slovenia & DIV & 4 & 4 & DIV \\
\hline Poland & 5 & 4 & 2 & 3 \\
\hline Romania & 5 & 4 & 2 & 4 \\
\hline Slovakia & 5 & 3 & 3 & 4 \\
\hline Czechia & 5 & 4 & 3 & 4 \\
\hline Hungary & 5 & 4 & 4 & 4 \\
\hline Croatia & 5 & 5 & 3 & 4 \\
\hline Estonia & 5 & 5 & 3 & 4 \\
\hline Cyprus & 5 & 6 & 2 & 3 \\
\hline Greece & 5 & 4 & DIV & 4 \\
\hline Latvia & 5 & 5 & DIV & 3 \\
\hline Lithuania & 5 & 4 & 5 & 3 \\
\hline Portugal & 5 & 5 & 5 & 3 \\
\hline Bulgaria & DIV & 6 & 4 & DIV \\
\hline
\end{tabular}

Notes. The table shows the EU27 countries (column 1) according to their total GVA phw club membership (column 2) over 2007-2018, as indicated in Table 2. Columns 3, 4 and 5 show, respectively, the clubs obtained with the PS methodology over 2007-2018 for sector C (manufacturing), KIS (J, K, M, N) and LKIS (G-I, L), as indicated in Table 5a, Table 5b and Table 5c.

At a glance, the countries that approach the higher productivity growth paths (i.e., Clubs 1 and 2) in all three sectors also fall in the higher clusters for total long-run economic 
productivity, namely, Clubs 1, 2, and 3. Only Luxembourg has relatively lower performance in manufacturing, which represents a very small share of its total GVA (see Table 3). The countries in Club 4, which are on more intermediate paths for total economy productivity growth, approach a lower long-run productivity path in manufacturing, as they cluster in Club 3 for that sector. Finally, the countries in the bottom cluster at the aggregate level, that is, Club 5 , approach the lower productivity growth paths in all three sectors. The exceptions are Slovakia in manufacturing and Poland, Romania, and Cyprus in the knowledge-intensive services.

\section{Has Economic Integration Led to Real Income Convergence in Europe?}

The findings of this analysis confirm that the CEECs mostly made progress in catching up to the rest of the EU before the global financial crisis and that unresolved asymmetries have amplified in the aftermath of the crisis. Some countries have benefitted from participating in the core manufacturing EU production network, but these countries remain remarkably distant from advanced EU countries, especially in the services sectors. This finding confirms that the manufacturing sector is an important source of knowledge diffusion for many countries in the process of catching up, although they are far from converging to core EU productivity levels.

Our results on the sector-level convergence patterns reflect the vertical specialization of the EU27 countries and their positioning in GVCs. Using the OECD TIVA dataset, we show the industry domestic value-added contributions to gross exports (TDVAIND, averages for 2005-2015) for the total manufacturing sector (VA Tot $\mathrm{C}$ ) and the high- and medium-high-skilled manufacturing sectors (VA High C) in Table 7a and for the knowledge-intensive services (KIS) in Table $7 \mathrm{~b}$. 
Table 7. Industry Domestic Value-Added Contribution to Gross Exports

Table 7a. Manufacturing (C)

\begin{tabular}{|c|c|c|c|c|}
\hline \multicolumn{5}{|c|}{$\mathrm{C}$} \\
\hline Clubs 1995-2018 & Countries & Clubs 2007-2018 & VA (Tot C)/Exp & VA (High C)/Exp \\
\hline DIV & Ireland & DIV & 29.72 & 20.80 \\
\hline 1 & Belgium & 1 & 29.65 & 13.84 \\
\hline 1 & Denmark & 1 & 28.20 & 14.65 \\
\hline & & $A V G C L U B \quad 1$ & 28.93 & 14.25 \\
\hline 1 & Austria & 2 & 38.12 & 18.60 \\
\hline 1 & France & 2 & 39.43 & 25.08 \\
\hline 1 & Germany & 2 & 53.00 & 36.75 \\
\hline 1 & Netherlands & 2 & 29.15 & 15.30 \\
\hline & & $A V G C L U B 2$ & 39.92 & 23.93 \\
\hline 1 & Finland & 3 & 46.85 & 23.40 \\
\hline 1 & Slovakia & 3 & 34.81 & 17.97 \\
\hline 1 & Sweden & 3 & 43.48 & 25.34 \\
\hline 1 & United Kingdom & 3 & 27.60 & 17.09 \\
\hline 2 & Italy & 3 & 47.12 & 23.47 \\
\hline 2 & Luxembourg & 3 & 4.87 & 1.12 \\
\hline 2 & Spain & 3 & 37.43 & 19.00 \\
\hline & & $A V G C L U B 3$ & 34.59 & 18.20 \\
\hline 1 & Lithuania & 4 & 30.68 & 8.39 \\
\hline 1 & Poland & 4 & 40.25 & 17.92 \\
\hline 2 & Czechia & 4 & 40.65 & 23.96 \\
\hline 2 & Greece & 4 & 20.36 & 4.65 \\
\hline 2 & Hungary & 4 & 31.89 & 20.70 \\
\hline 2 & Romania & 4 & 42.33 & 20.94 \\
\hline 2 & Slovenia & 4 & 38.58 & 19.86 \\
\hline & & $A V G C L U B 4$ & 34.96 & 16.63 \\
\hline 2 & Croatia & 5 & 24.77 & 7.87 \\
\hline 2 & Estonia & 5 & 28.36 & 8.64 \\
\hline 2 & Portugal & 5 & 37.86 & 12.49 \\
\hline 3 & Latvia & 5 & 27.62 & 4.56 \\
\hline & & $A V G C L U B 5$ & 29.66 & 8.39 \\
\hline 3 & Bulgaria & 6 & 26.23 & 7.05 \\
\hline 3 & Cyprus & 6 & 5.89 & 1.71 \\
\hline & & $A V G C L U B 6$ & 16.06 & 4.38 \\
\hline
\end{tabular}

Notes. The table shows the industry domestic value-added contribution to gross exports (averages 2005-2015) of total Manufacturing sector (VA Tot C) and High and Medium-High skill Manufacturing sector (VA High C) for the EU27 (Eurostat and Tiva dataset, OECD). Clubs are obtained with the PS methodology using the log $t$ test for 1995-2018 (column 1) and 2007-2018 (column 3), as indicated in Table 4d and Table 5a, respectively. 
Table 7. Continued

Table 7b. KIS (J, K, M, N and J, M, N)

\begin{tabular}{|c|c|c|c|c|}
\hline \multicolumn{4}{|c|}{$\mathrm{J}, \mathrm{K}, \mathrm{M}, \mathrm{N}$} & \multirow{2}{*}{$\frac{\mathrm{J}, \mathrm{M}, \mathrm{N}}{\mathrm{VA} / \operatorname{Exp}}$} \\
\hline Clubs 1995-2018 & Countries & Clubs 2007-2018 & VA/Exp & \\
\hline 1 & Ireland & 1 & 19.31 & 11.66 \\
\hline \multirow[t]{2}{*}{1} & Luxembourg & 1 & 23.95 & 8.23 \\
\hline & & $A V G C L U B 1$ & 21.63 & 9.94 \\
\hline 1 & Sweden & DIV & 13.78 & 12.11 \\
\hline 2 & Denmark & DIV & 6.86 & 5.92 \\
\hline 2 & Germany & DIV & 9.62 & 7.22 \\
\hline 2 & Belgium & 2 & 15.07 & 12.19 \\
\hline 2 & Cyprus & 2 & 31.12 & 19.84 \\
\hline 2 & France & 2 & 11.30 & 9.39 \\
\hline 2 & Netherlands & 2 & 15.30 & 12.64 \\
\hline 2 & Romania & 2 & 10.43 & 9.58 \\
\hline 2 & United Kingdom & 2 & 31.18 & 16.56 \\
\hline \multirow[t]{2}{*}{3} & Poland & 2 & 6.88 & 6.22 \\
\hline & & $A V G C L U B 2$ & 17.33 & 12.34 \\
\hline 2 & Austria & DIV & 10.75 & 7.69 \\
\hline 3 & Finland & DIV & 10.43 & 9.60 \\
\hline 3 & Italy & DIV & 6.64 & 5.24 \\
\hline 3 & Spain & DIV & 10.84 & 8.74 \\
\hline 3 & Croatia & 3 & 12.97 & 10.17 \\
\hline 3 & Czechia & 3 & 5.66 & 5.06 \\
\hline 3 & Estonia & 3 & 9.79 & 8.37 \\
\hline \multirow[t]{2}{*}{3} & Slovakia & 3 & 3.88 & 3.29 \\
\hline & & $A V G C L U B 3$ & 8.08 & 6.72 \\
\hline 4 & Bulgaria & 4 & 8.15 & 6.69 \\
\hline 4 & Hungary & 4 & 6.61 & 6.21 \\
\hline \multirow[t]{2}{*}{4} & Slovenia & 4 & 6.09 & 5.17 \\
\hline & & $A V G C L U B 4$ & 6.95 & 6.02 \\
\hline 4 & Lithuania & 5 & 3.65 & 3.21 \\
\hline \multirow[t]{2}{*}{4} & Portugal & 5 & 5.72 & 4.75 \\
\hline & & $A V G C L U B 5$ & 4.69 & 3.98 \\
\hline 4 & Greece & DIV & 5.76 & 4.26 \\
\hline 4 & Latvia & DIV & 11.83 & 7.43 \\
\hline
\end{tabular}

Notes. The table shows the industry domestic value-added contribution to gross exports (averages 2005-2015) of total KIS sectors $(J, K, M, N)$ on the left, and of KIS sectors excluding financial and insurance activities $(\mathrm{K})$ on the right, for the EU27 (Eurostat and Tiva dataset, OECD). Clubs are obtained with the PS methodology using the $\log t$ test for 1995-2018 (column 1) and 2007-2018 (column 3), as indicated in Table 4e and Table 5b, respectively. 
For convenience, we report the baseline and sub-period club memberships obtained using the PS methodology (columns 1 and 3). The TDVAIND indicates a given industry's importance with respect to other industries. The data confirm that the manufacturing sector plays a driving role in Poland, the Czech Republic, Romania, and Slovenia, with shares of about $40 \%$ or more in these countries, although the highest share of manufacturing is in Germany (53\%), followed by Italy and Finland (about 47\%) and Sweden (43\%). The high- and medium-high-skilled manufacturing sectors make the greatest contribution in Germany (about 37\%), followed by Sweden and France (about 25\%); the Czech Republic, Italy, and Finland (slightly below 24\%); and Ireland, Romania, and Hungary (around 20\%). Notably, the high- and medium-high-skilled manufacturing sectors contribute little value added to gross exports in the countries in Clubs 5 and 6 and in Lithuania and Greece, even though the contributions of the total manufacturing sectors in these countries are slightly below $30 \%$ in most cases. Luxembourg, the UK, and Cyprus have the highest TDVAIND intensities for the knowledge-intensive sector, and the financial services sector $(\mathrm{K})$ is particularly relevant, as shown by comparing the values in columns 2 and 3 .

We can obtain additional insights by comparing the foreign intensity measure of value added (FVA) across EU countries. The FVA describes the import content of exports and is considered a measure of backward linkages in analyses of GVCs. Figure 8 shows the average FVA positions

Figure 8. Foreign value-added share of gross exports, manufacturing and subsectors

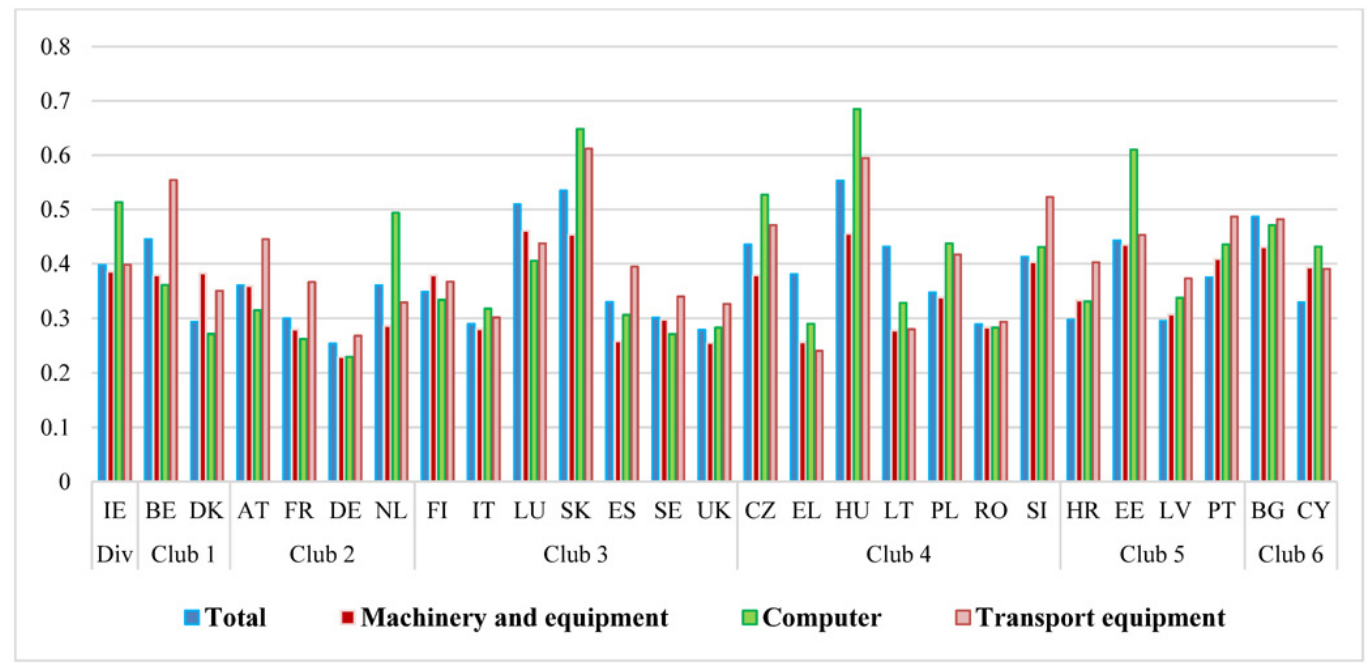

Notes. The histogram shows the foreign value-added share of gross exports over the period 2005-2016 for: Total Manufacturing (sector C, blue bar), Machinery and Equipment (C29-30, red bar), Computer (sector C26-27, green bar), Transport equipment (sector C28, yellow bar). (Tiva database, OECD). Countries are ordered according to their GVA phw club membership for Manufacturing (see Table 5a): IE (Ireland), BE (Belgium), DK (Denmark), AT (Austria), FR (France), DE (Germany), NL (Netherlands), FI (Finland), IT (Italy), LU (Luxembourg), SK (Slovakia); ES (Spain), SE (Sweden), UK (United Kingdom), CZ (Czechia), EL (Greece), HU (Hungary), LT (Lithuania), PL (Poland), RO (Romania), SI (Slovenia), HR (Croatia), EE (Estonia), LV (Latvia), PT (Portugal), BG (Bulgaria), CY (Cyprus). 
of the $27 \mathrm{EU}$ countries, grouped according to their respective club memberships, for the period 2005-2016. We show data for the total manufacturing sector (C) and for selected innovation-intensive subsectors, namely, machinery and equipment (C29-30), transport equipment (C28), and computers (C26-27). We observe high import contents of exports for the countries integrated in the core EU production networks. In particular, Hungary and Slovakia stand out with FVAs between $60 \%$ and $70 \%$ in the computer and transport and equipment industries, as do the Czech Republic and Slovenia.

Finally, we make some further considerations regarding the determinants of the structural convergence patterns. As the endogenous growth theory literature has emphasized since the early contributions of Romer (1990, 1994), productivity growth is strongly driven by countries' engagement in $R \& D$ activities, which require human capital. In addition, the endowment of a skilled labor force allows countries to benefit from the international diffusion of knowledge channeled by international trade. In other words, the presence of absorptive capabilities allows less-developed countries to benefit from integration with advanced economies (Abramovitz, 1986). Overall, growth theory predicts that countries with similar endowments of researchers, engagement in $\mathrm{R} \& \mathrm{D}$, and patenting efforts will approach a common productivity growth path. Table 8 compares the positions of the 27 EU countries in terms of R\&D expenditures (share of GDP), human capital (researchers per thousand workers), and patents.

The old northwestern EU member states score the highest along these dimensions. Among the new EU member states, Slovenia, the Czech Republic, Hungary, and Estonia are in relatively favorable positions, which can explain their successful integration into the EU's core manufacturing networks. These countries' exports are very import-intensive and are characterized by relatively low domestic value added, whereas countries that specialize in the design and engineering phases of output produce upstream, high-value components. From this perspective, the initial strong gains from integration owing to very large cross-country income differences tend to diminish, especially in the face of increasing competition from less advanced economies. In such economies, the labor cost advantage offsets the other costs of offshoring, leading to continuous change in the structures of global production networks. Thus, international competition poses a challenge for firms in less advanced EU countries to upgrade their vertical specializations and their positions in the GVCs.

Other important factors can explain countries' tendencies to group together or diverge, including the development of financial markets and institutions (Cavallaro \& Villani, 2020), agglomeration effects, and regulatory features. These determinants can strongly impact the integration process's ability to deliver the expected convergence. Thus, national and pan-European policies to mitigate cross-country differences in these factors are crucial for the structural adjustments that are still needed to achieve convergence. 
Table 8. R\&D, Researchers and Patents, Average 2007-2018

\begin{tabular}{|c|c|c|c|}
\hline Countries & R\&D (\% GDP) & $\begin{array}{c}\text { Researchers per thousand } \\
\text { labour force }\end{array}$ & Patents (numbers) \\
\hline Ireland & 1.40 & 8.80 & 344.42 \\
\hline Luxembourg & 1.40 & 10.03 & 69.48 \\
\hline Belgium & 2.28 & 9.38 & 1537.84 \\
\hline Denmark & 2.94 & 13.56 & 1343.83 \\
\hline France & 2.19 & 9.02 & 9010.93 \\
\hline Germany & 2.84 & 8.42 & 21961.71 \\
\hline Netherlands & 1.87 & 7.70 & 3402.43 \\
\hline Austria & 2.86 & 9.16 & 1856.76 \\
\hline Finland & 3.24 & 14.46 & 1440.09 \\
\hline Italy & 1.28 & 4.57 & 4423.28 \\
\hline Spain & 1.28 & 5.53 & 1529.54 \\
\hline Sweden & 3.28 & 11.57 & 2933.92 \\
\hline United Kingdom & 1.64 & 8.15 & 5460.35 \\
\hline Slovenia & 2.07 & 8.02 & 121.46 \\
\hline Lithuania & 0.9 & 5.68 & 23.37 \\
\hline Poland & 0.85 & 4.27 & 455.02 \\
\hline Romania & 0.5 & 1.96 & 67.53 \\
\hline Croatia & 0.82 & 3.66 & 21.89 \\
\hline Cyprus & 0.47 & 2.06 & 8.70 \\
\hline Czechia & 1.64 & 6.33 & 246.76 \\
\hline Estonia & 1.52 & 6.28 & 32.61 \\
\hline Greece & 0.81 & 5.67 & 94.95 \\
\hline Hungary & 1.23 & 5.37 & 202.06 \\
\hline Latvia & 0.59 & 3.54 & 25.51 \\
\hline Portugal & 1.36 & 7.52 & 120.52 \\
\hline Slovakia & 0.74 & 5.20 & 45.15 \\
\hline Bulgaria & 0.64 & 3.83 & 27.58 \\
\hline
\end{tabular}

Notes. The table shows the average R\&D, researchers in R\&D per thousand labour force and patents data over 2007-2018 (Eurostat and World Bank data). R\&D correspond to the intramural R\&D expenditure as \% of GDP, while patents data correspond to number of patent applications to the EPO by priority year.

\section{Conclusion}

This study assessed recent trends in productivity convergence both for overall economies and at the sector level within the EU. Our analysis sheds light on the impact of countries' vertical specializations and on the related differences in real income at the industry level. Our results suggest a noticeable fragmentation in both aggregate and sectoral productivity, with 
multiple long-run equilibria for subgroups of countries. The asymmetries that we observe are not homogeneous across sectors and are larger in the knowledge-intensive sector. We compare the results for the full period, which we define as our baseline results, with findings for the period 2007-2018. In the latter period, we identify more clusters, partly because the shorter period reduces the possibility for adjustments in the transitional dynamics but also because of the increased asymmetries. The relative changes in the clubs' position help us to identify the evolutionary process. To draw further insights on the asymmetries in long-run productivity growth, we analyze the domestic value-added shares of gross exports by industry, particularly for total manufacturing, innovation-intensive manufacturing, and knowledge-intensive services. We also illustrate the relationship with countries' backward participation linkages in GVCs, which show the import contents of exports. These data confirm that manufacturing drives knowledge diffusion for the new EU member states that have successfully integrated into the core EU countries' production networks. Nevertheless, the post-crisis evolution suggests that these countries' process of catching up has lost momentum and that more effort is needed to close the long-run growth gap.

We conclude that two factors hinder convergence for the countries that approach the lower productivity growth paths: the lower shares of the innovation-intensive and high-skilled sectors and the lower productivities of these sectors, reflecting their positioning in the GVCs. This result shows that the integration process within the EU, as measured by production structure similarities, is far from being achieved. These asymmetries can increase vulnerability to adverse domestic and foreign shocks and, in view of the trends of shifting production processes to less advanced countries, to relevant labor cost differentials. Our findings suggest a need for further research on this topic to understand the appropriate policies that can address the issue of multiple growth paths within Europe and induce the necessary structural adjustments to achieve global convergence.

\section{References}

Abramovitz, M. (1986). Catching up, forging ahead, and falling behind. Journal of Economic History, $46(2), 385-406$.

Aiginger, K. (1997). The use of unit values to discriminate between price and quality competition. Cambridge Journal of Economics, 21(5), 571-592.

Aiyar, S., Augustyniak, B., Ebeke, C., Ebrahimy, E., Elekdag, S., Klein, N., Lall, S., Zhao, H., \& Muir, D. (2013). Multi-country report. German-central European supply chain - cluster report. IMF Country Report No. 13/263, August.

Apergis, N., Panopulu, E., \& Tsoumas, C. (2010). Old wine in a new bottle: Growth convergence dynamics 
in the EU. Atlantic Economic Journal, 38(2), 169-181.

Azariadis, C. (1996). The economics of poverty traps part one: Complete markets. Journal of Economic Growth, 1(4), 449-486.

Azariadis, C., \& Drazen, A. (1990). Threshold externalities in economic development. Quarterly Journal of Economics, 105(2), 501-526.

Baldwin, R., \& Lopez-Gonzalez, J. (2014). Supply-chain trade: A portrait of global patterns and several testable hypotheses. The World Economy, 38(11), 1682-1721.

Baldwin, R., \& Venables, A. J. (2013). Spiders and snakes: Offshoring and agglomeration in the global economy. Journal of International Economics, 90(2), 245-254.

Baldwin, R., \& Wyplosz, C. (2009). The economics of European integration, 3rd ed. Europe, Middle East \& Africa: McGraw-Hill.

Baltagi, B. H., \& Li, Q. (2002). On instrumental variable estimation of semiparametric dynamic panel data models. Economics Letters, 76(1), 1-9.

Barro, R. J., \& Sala-i-Martin, X. (1992). Convergence. Journal of Political Economy, 100(2), 223-251.

Barro, R., \& Sala-i-Martin, X. (1997). Technological diffusion, convergence, and growth. Journal of Economic Growth, 2(1), 1-27.

Bartkowska, M., \& Riedl, A. (2012). Regional convergence clubs in Europe: Identification and conditioning factors. Economic Modelling, 29(1), 22-31.

Basu, S., \& Weil, D. N. (1998). Appropriate technology and growth. Quarterly Journal of Economics, 113(4), 1025-1054.

Baumol, W. J. (1986). Productivity growth, convergence, and welfare: What the long-run data show. American Economic Review, 76(5), 1072-1085.

Beck, R., Dedola, L., Giovannini, A., \& Popov, A. (2016). Financial integration and risk sharing in a monetary union. Financial Integration in Europe. Special Feature A. European Central Bank, April.

Becker, T. D. D., Darvas, Z., Gligorov, V., Landesmann, M., Petrovic, P., Pisani-Ferry, J., Rosati, D., Sapir, A., \& Weder Di Mauro, A. (2010). Whither growth in Central and Eastern Europe? Policy lessons for an integrated Europe. Bruegel Blueprint Series, Vol XI: Brussels. Retrieved from https://www.bruegel.org/2010/11/whither-growth-in-central-and-eastern-europe-policy-lessons-for-an-i ntegrated-europe/

Bernard, A. B., \& Durlauf, S. N. (1996). Interpreting tests of the convergence hypothesis. Journal of Econometrics, 71(1-2), 161-173.

Bils, M., \& Klenow, P. J. (2001). Quantifying quality growth. American Economic Review, 91(4), 1006-1030.

Bolea, L., Duarte, R., \& Sanchez Choliz, J. (2018). From convergence to divergence? Some new insights into the evolution of the European Union. Structural Change and Economic Dynamics, 47(C), 82-95.

Borsi, M. T., \& Metiu, N. (2015). The evolution of economic convergence in the European Union. Empirical Economics, 48(2), 657-681.

Brooks, E. L. (2006). Why don't firms export more? Product quality and Colombian plants. Journal of Development Economics, 80(1), 160-178.

Buelens, C., \& Tirpák, M. (2017). Reading the footprints: How foreign investors shape countries' 
participation in global value chains. Comparative Economic Studies, 59(5), 561-584.

Butterworth, S. (1930). On the theory of filter amplifiers. Experimental Wireless and the Wireless Engineer, 7, 536-541, October.

Cai, Z., \& Li, Q. (2008). Nonparametric estimation of varying coefficient dynamic panel data models. Economic Theory, 24(5), 1321-1342.

Califano A., \& Gasperin S. (2019). Multi-speed Europe is already there: Catching up and falling behind. Structural Change and Economic Dynamics, 51(C), 152-167, December.

Cavallaro, E., Esposito, P., Matano, A., \& Mulino, M. (2013). Technological catching up, quality of exports, and competitiveness. Emerging Markets Finance and Trade, 49(6), 4-21.

Cavallaro, E., \& Villani, I. (2020). Real income convergence and the patterns of financial integration in the EU. North American Journal of Economics and Finance. In print. https://doi.org/10.1016/j.najef. 2020.101337.

Crinò, R., \& Epifani, P. (2012). Productivity, quality and export behaviour. The Economic Journal, 122(565), 1206-1243.

Cutrini, E. (2019). Economic integration, structural change, and uneven development in the European Union. Structural Change and Economic Dynamics, 50, 102-113.

Du, K. (2017). Econometric convergence test and club clustering using Stata. Stata Journal, 17(4), 882-900.

Dulleck, U., Foster, N., Strehrer, R., \& Woerz, J. (2005). Dimensions of quality upgrading: Evidence from CEECs. Economics of Transition, 13(1), 51-76.

Evans, P. (1998). Using panel data to evaluate growth theories. International Economic Review, 39(2), 295-306.

Evans, P., \& Karras, G. (1996). Convergence revisited. Journal of Monetary Economics, 37(2), 249-265.

Galor, O. (1996). Convergence? Inferences from theoretical models. The Economic Journal, 106(437), 1056-1069.

Hallak, J. C. (2010). A product-quality view of the Linder hypothesis. Review of Economics and Statistics, 92(3), 453-466.

Hoffmann, M., \& Sorensen, B. (2015). Small firms and domestic bank dependence in Europe's great recession. European Economics, Discussion Paper 012. Directorate General Economic and Financial Affairs (DG ECFIN), European Commission.

Howitt, P., \& Mayer-Foulkes, D. (2005). R\&D, implementation and stagnation: A Schumpeterian theory of convergence clubs. Journal of Money, Credit and Banking, 37(1), 147-177.

Hummels, D., Ishii, J., \& Yi, K.-M. (2001). The nature and growth of vertical specialization in world trade. Journal of International Economics, 54(1), 75-96.

Islam, N. (1995). Growth empirics: A panel data approach. Quarterly Journal of Economics, 110(4), 1127-1170.

Kremer, M., \& Popov, A. (2018). Financial development, financial structure and growth: Evidence from Europe. Financial Integration in Europe. Special feature A. European Central Bank, May.

Krugman, P. (1991). Geography and trade. Cambridge, MA: MIT Press.

Landesmann, M., Leitner, S., Stehrer, R., \& Ward, T. (2009). Skills and industrial competitiveness. WIIW Research Report No. 356, August. 
Landesmann, M., \& Stehrer, R. (2007). Income distribution, technical change and the dynamics of international competitiveness. Metroeconomica, 78(1), 45-73.

Landesmann, M. A., \& Stöllinger, R. (2019). Structural change, trade and global production networks: An 'appropriate industrial policy' for peripheral and catching-up economies. Structural Change and Economic Dynamics, 48(C), 7-23.

Li, Q., \& Stengos, T. (1996). Semiparametric estimation of partially linear panel data models. Journal of Econometrics, 71(1-2), 389-397.

Linder, S. (1961). An essay on trade and transformation. Stockholm: Almqvist and Wiksell.

Lucas, R. E. (1988). On the mechanism of economic development. Journal of Monetary Economics, 22(1), $3-42$.

Lyncker, K., \& Thoennessen, R. (2017). Regional club convergence in the EU: Evidence from a panel data analysis. Empirical Economics, 52(2), 525-553.

Mankiw, N. G., Romer, D., \& Weil, D. N. (1992). A contribution to the empirics of economic growth. Quarterly Journal of Economics, 107(2), 407-437.

Monfort, M., Cuestas, J. C., \& Ordonez, J. (2013). Real convergence in Europe: A cluster analysis. Economic Modelling, 33(C), 689-694.

Nilsson, R., \& Gyomai G. (2011). Cycle extraction: A comparison of the phase-average trend method, the Hodrick-Prescott and Christiano-Fitzgerald filters. OECD Statistics Working Papers, No. 2011/04. Paris.

Palan, N., \& Schmiedeberg, C. (2010). Structural convergence of European countries. Structural Change and Economic Dynamics, 21(2), 85-100.

Parente, S., \& Prescott, E. (1994). Barriers to technology adoption and development. Journal of Political Economy, 102(2), 298-321.

Perez-Sebastian F. (2000). Transitional dynamics in an R\&D-based growth model with imitation: Comparing its predictions to the data. Journal of Monetary Economics, 45(2), 437-461.

Pesaran, M., \& Smith, R. (1995). Estimating long-run relationships from dynamic heterogeneous panels. Journal of Econometrics, 68(1), 79-113.

Phillips, P. C. B., \& Sul, D. (2007). Transition modelling and econometric convergence tests. Econometrica, 75(6), 1771-1855.

Phillips, P. C. B., \& Sul, D. (2009). Econometric transition and growth. Journal of Applied Economics, 24(7), 1153-1185.

Robertson, D., \& Symons, J. (1992). Some strange properties of panel data estimators. Journal of Applied Economics, 7(2), 175-189.

Romer, P. M. (1986). Increasing returns and long run growth. Journal of Political Economy, 94(5), 1002-1037.

Romer, P. M. (1990). Endogenous technological change. Journal of Political Economy, 98(5), 71-102.

Romer, P. M. (1994). The origins of endogenous growth. Journal of Economic Perspectives, 8(1), 3-22.

Schnurbus, J., Haupt, H., \& Meier, V. (2017). Economic transition and growth: A replication. Journal of Applied Economics, 32(5), 1039-1042.

Schott, P. (2004). Across-product versus within-product specialization in international trade. Quarterly 
Journal of Economics, 119(2), 647-678.

Sondermann, D. (2014). Productivity in the euro area: Any evidence of convergence? Empirical Economics, 47(3), 999-1027.

Stehrer, R. \& Stöllinger, R. (2014). The Central European manufacturing core: What is driving regional production sharing? FIW-Research Reports 2014/15, No. 02. 


\section{Appendix}

Table A1. Results of Log $t$ test for Productivity, Total Economy, 1995-2006

\begin{tabular}{|c|c|c|c|c|c|c|}
\hline & $\begin{array}{c}\text { No. of } \\
\text { Countries }\end{array}$ & $b$ & $T$-Stat & SE & $\begin{array}{l}\text { GVA phw } \\
1995 \\
\text { (Average) }\end{array}$ & $\begin{array}{l}\text { GVA phw } \\
2006 \\
\text { (Average) }\end{array}$ \\
\hline WHOLE SAMPLE & 27 & -0.9869 & -40.5036 & 0.0244 & 26.20 & 30.85 \\
\hline $\begin{array}{l}\text { Club } 1 \\
\text { Austria, Belgium, Denmark, Finland, France, } \\
\text { Germany, Ireland, Netherlands, Sweden }\end{array}$ & 9 & -0.0008 & -0.0204 & 0.0378 & 32.29 & 41.44 \\
\hline $\begin{array}{l}\text { Club } 2 \\
\text { Cyprus, Greece, Italy, Slovakia, Slovenia, } \\
\text { Spain, United Kingdom }\end{array}$ & 7 & 0.0988 & 1.1426 & 0.0864 & 25.17 & 28.17 \\
\hline $\begin{array}{l}\text { Club } 3 \\
\text { Croatia, Czechia, Estonia, Hungary, Latvia, } \\
\text { Lithuania, Poland, Portugal }\end{array}$ & 8 & 0.3134 & 2.6596 & 0.1178 & 17.84 & 19.64 \\
\hline $\begin{array}{l}\text { Club } 4 \\
\text { Bulgaria, Romania }\end{array}$ & 2 & 5.4361 & 3.9767 & 1.3670 & 15.68 & 14.06 \\
\hline $\begin{array}{l}\text { DIVERGENT } \\
\text { Luxembourg }\end{array}$ & 1 & - & - & - & - & - \\
\hline
\end{tabular}

Notes. GVA phw is total GVA per-hour worked, PPP-adjusted constant 2015 Euro prices (Eurostat). Truncation parameter: $r=0.3$. Critical value: $c=0 . T$-Statistic at the $5 \%$ significance level: -1.645 .

Table A2. Results of Log $t$ test for Productivity, Total Economy, Sub-Sample Old EU Member States, 1995-2018

\begin{tabular}{|c|c|c|c|c|c|c|}
\hline & $\begin{array}{l}\text { No. of } \\
\text { Countries }\end{array}$ & $b$ & $T$-Stat & SE & $\begin{array}{l}\text { GVA phw } \\
1995 \\
\text { (Average) }\end{array}$ & $\begin{array}{l}\text { GVA phw } \\
2018 \\
\text { (Average) }\end{array}$ \\
\hline WHOLE SAMPLE & 15 & -0.8306 & -102.2001 & 0.0081 & 32.82 & 42.14 \\
\hline $\begin{array}{l}\text { Club } 1 \\
\text { Belgium, Denmark, France, Germany, } \\
\text { Ireland, Luxembourg }\end{array}$ & 6 & -0.0917 & -1.5724 & 0.0583 & 38.00 & 51.80 \\
\hline $\begin{array}{l}\text { Club } 2 \\
\quad \text { Austria, Netherlands, Sweden, United } \\
\text { Kingdom }\end{array}$ & 4 & 0.6480 & 17.7761 & 0.0365 & 31.60 & 42.04 \\
\hline $\begin{array}{l}\text { Club } 3 \\
\quad \text { Finland, Italy, Spain }\end{array}$ & 3 & 0.5693 & 2.4104 & 0.2362 & 32.82 & 36.13 \\
\hline $\begin{array}{l}\text { Club } 4 \\
\quad \text { Greece, Portugal }\end{array}$ & 2 & 6.1268 & 3.8074 & 1.6092 & 19.73 & 22.39 \\
\hline
\end{tabular}

Notes. GVA phw is total GVA per-hour worked, PPP-adjusted constant 2015 Euro prices (Eurostat). Truncation parameter: $r=0.3$. Critical value: $c=0 . T$-Statistic at the $5 \%$ significance level: -1.645 . 